\title{
TEORES DE CARBOIDRATOS EM PESSEGUEIROS (Prunus persica (L.) Batsch.) SUBMETIDOS A DIFERENTES TIPOS DE PODA
}

\section{MARCELO REHDER DA CUNHA BORBA}

Engenheiro Agrônomo

Orientador: Prof. Dr. JOÃO ALEXIO SCARPARE FILHO

Dissertação apresentada à Escola Superiơ de Agricultura "Luiz de Queiroz", Universidade de São Paulo, para obtenção do título de Mestre em Agronomia, área de concentração: Fitotecnia

PIRACICABA

Estado de São Paulo - Brasil

Abril - 2002 

Dados Internacionais de Catalogação na Publicação (CIP)
DIVISÃO DE BIBLIOTECA E DOCUMENTAÇÃO - ESALQ/USP

\footnotetext{
Borba, Marcelo Rehder da Cunha

Teores de carboidratos em pessegueiros (Prunus persica (L.) Batsch) submetidos a diferentes tipos de poda / Marcelo Rehder da Cunha Borba. - Piracicaba, 2002.

$51 \mathrm{p}$.

Dissertação (mestrado) - - Escola Superior de Agricultura Luiz de Queiroz, 2002.

Bibliografia.

1. Carboidratos-teor 2. Pêssego 3. Poda I. Título
} 
À minha esposa SOFIA

e a meus filhos BRENO e CÁSSIO

pelo amor, apoio, incentivo e compreensão

Aos meus pais ADDY e DALTRO

pelo amor e oportunidade gerada desde a minha infância

Ao meu avô HANS (in memoriam)

pela semente

DEDICO 


\section{AGRADECIMENTOS}

Ao Prof. Dr. João Alexio Scarpare Filho, pela orientação, ensinamentos, auxílio, compreensão e amizade.

À Escola Superior de Agricultura "Luiz de Queiróz", Universidade de São Paulo, por acreditar em nosso potencial e possibilitar a realização do curso.

À CAPES, pela concessão da bolsa de estudos.

Aos funcionários do Departamento de Produção Vegetal, em especial a David, Éder, Aparecido e Helena, e às secretárias Célia, Bete e Ivete, pela atenção dispensada.

Aos professores do curso de Pós-Graduação em Fitotecnia da ESALQ/USP, pelos ensinamentos ministrados, em especial aos professores Ricardo Victória Filho e Ângelo Pedro Jacomino.

Aos professores do Departamento de Produção Vegetal, pelo convívio.

Aos amigos conquistados, pela amizade e agradável convivência.

A Deus, pelo material para a realização deste trabalho.

A Jesus, pela luz sobre meu caminho. 


\section{SUMÁRIO}

Página

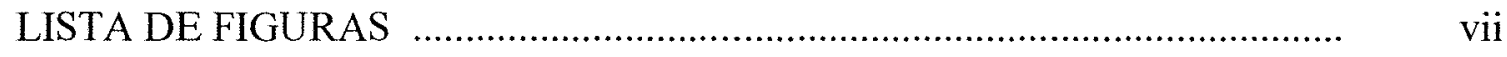

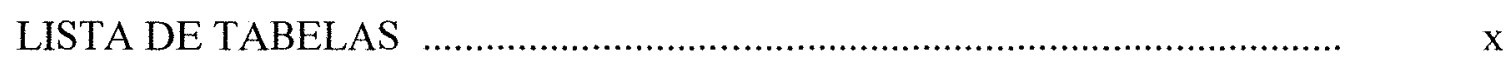

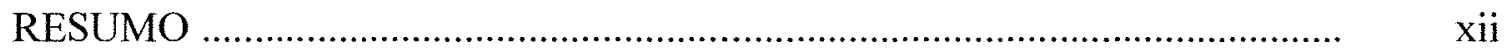

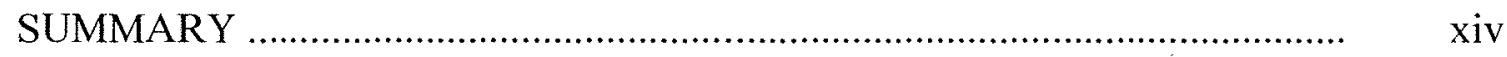

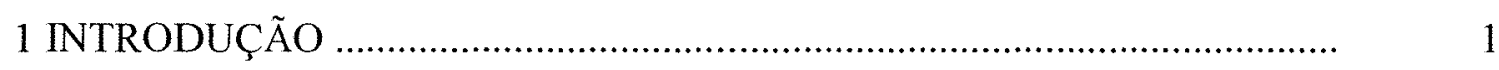

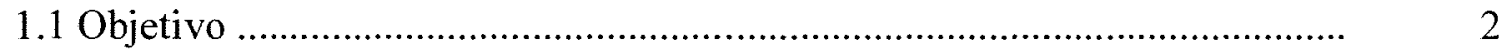

2 REVISÃO DE LITERATURA

2.1 Origem, distribuição e classificação botânica ............................................. 3

2.1.1 Origem e distribuição ................................................................ 3

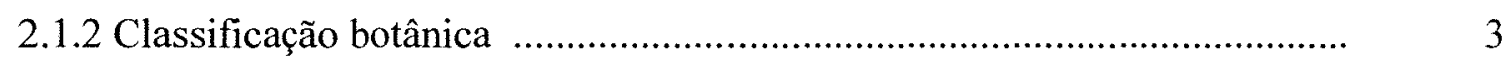

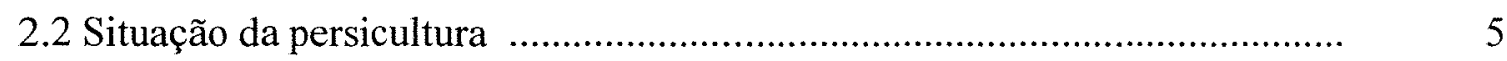

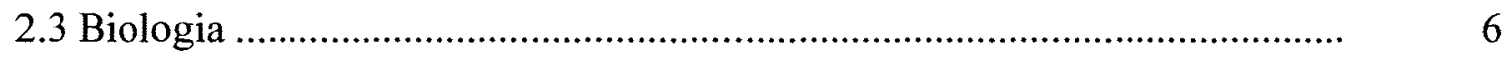

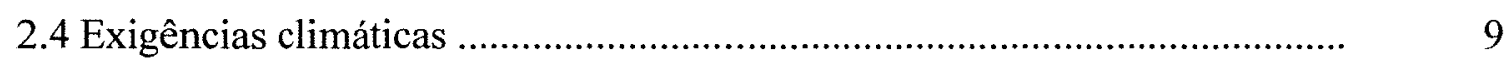

2.5 Poda .......................................................................................... 10

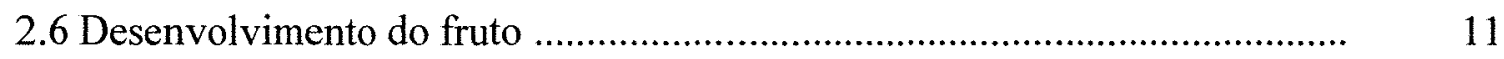

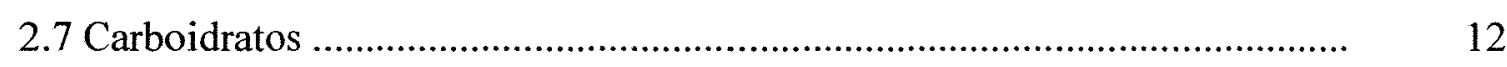

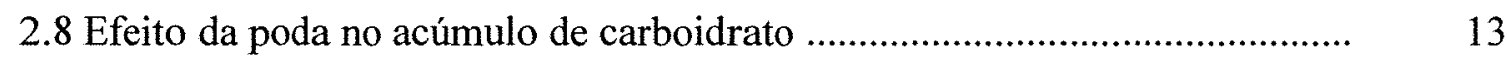

3 MATERIAL E MÉTODOS ................................................................... 15

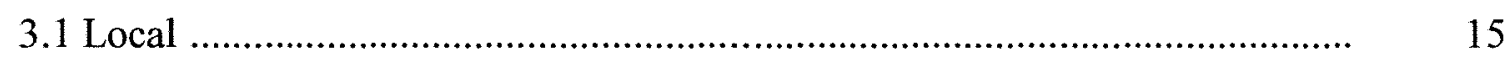

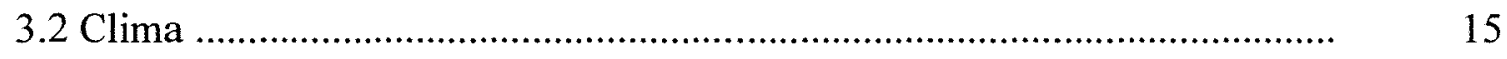

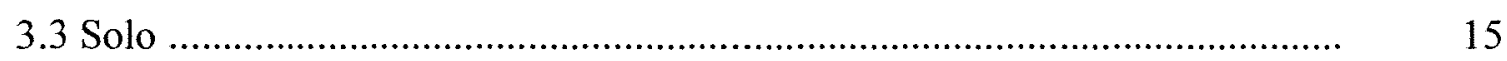

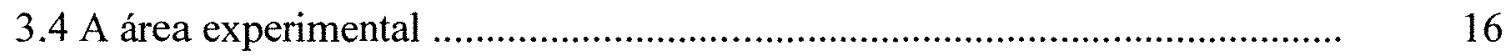




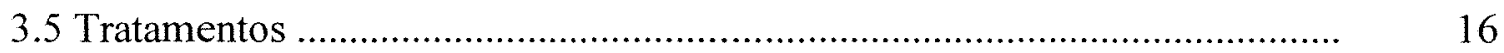

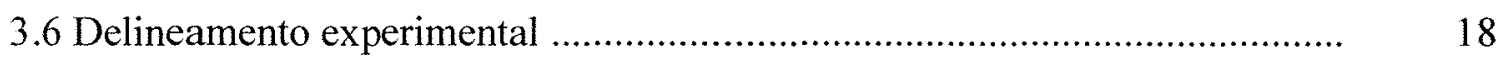

3.7 Retirada e preparo das amostras para análise ……………........................... 19

3.8 Carboidratos analisados ..................................................................... 20

3.9 Determinação de carboidratos solúveis totais - método de Somogyi e

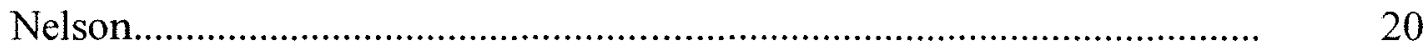

3.10 Determinação dos açúcares redutores ........................................................... 22

3.11 Análise estatística ................................................................................ 24

4 RESULTADOS E DISCUSSÃO ………………..................................

4.1 Carboidratos solúveis totais nas raízes ......................................................... 25

4.2 Carboidratos solúveis totais na copa ........................................................ 29

4.3 Comparação entre carboidratos solúveis totais no sistema radicular e na

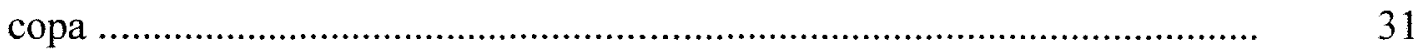

4.4 Açúcares redutores no sistema radicular ..................................................... 32

4.5 Teor de açúcares redutores na copa ...........................................................

4.6 Comparação entre açúcares redutores no sistema radicular e na copa .......... 35

4.7 Teor de sacarose na raiz ...........................................................................

4.8 teor de sacarose na copa .................................................................. 38

4.9 Comparação entre carboidratos translocáveis (sacarose) no sistema radicular e na copa ..................................................................................... 40

4.10 Influência do tipo de poda na produtividade .................................................. 41

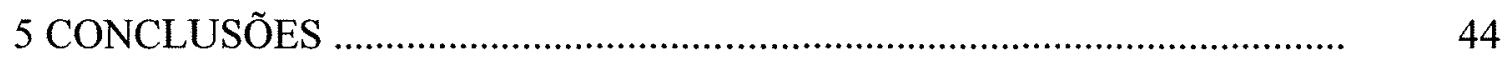

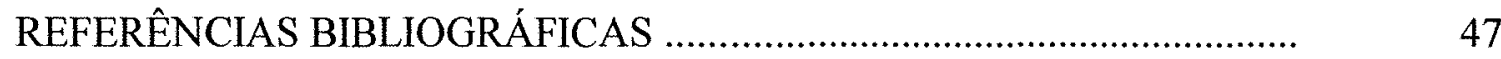




\section{LISTA DE FIGURAS}

Página

1 Esquema dos tratamentos de podas leve e renovação realizadas nos pessegueiros logo após a colheita dos frutos

2 Diferenças de copas, logo após a poda, entre as plantas submetidas à poda de renovação e à poda leve realizados em pessegueiros Ouromel-2 em Piracicaba, SP

3 Croqui do delineamento em blocos ao acaso na área experimental da escola Superior de Agricultura "Luiz de Queiroz", Piracicaba, SP .....

4 Efeito de dois tipos de poda no teor de carboidratos solúveis totais (mg/100 ml) no sistema radicular de pessegueiros 'Ouromel-2' em diferentes fases de um ciclo, em Piracicaba, SP

5 Crescimento dos ramos novos em pessegueiros 'Ouromel-2' (mm) submetidos ao tratamento de poda de renovação, em Piracicaba, SP

6 Ramo em janeiro, no final do crescimento, de pessegueiro cultivar 'Ouromel-2' tratado com poda de renovação, em Piracicaba, SP 
7 Diferenças no desenvolvimento de ramos entre pessegueiros cultivar 'Ouromel-2', tratados com dois tipos de poda, em Piracicaba, SP

8 Efeito de dois tipos de poda no teor de carboidratos solúveis totais $(\mathrm{mg} / 100 \mathrm{ml})$ na copa de pessegueiros 'Ouromel-2' durante o período de um ciclo, em Piracicaba, SP

9 Comparativo dos teores de carboidratos solúveis totais $(\mathrm{mg} / 100 \mathrm{ml})$ entre copa e sistema radicular de pessegueiros 'Ouromel-2' durante o período de um ciclo, em Piracicaba, SP

10 Efeito de dois tipos de poda no teor de açúcares redutores $(\mathrm{mg} / 100 \mathrm{ml})$ no sistema radicular de pessegueiros 'Ouromel-2' durante o período de um ciclo, em Piracicaba, SP

11 Efeito de dois tipos de poda no teor de açúcares redutores $(\mathrm{mg} / 100 \mathrm{ml})$ na copa de pessegueiros 'Ouromel-2' durante o período de um ciclo, em Piracicaba, SP

12 Comparativo dos teores de açúcares redutores $(\mathrm{mg} / 100 \mathrm{ml})$ entre copa e sistema radicular de pessegueiros 'Ouromel 2' durante o período de um ciclo, em Piracicaba, SP

13 Teores de sacarose em raízes de pessegueiro 'Ouromel-2' (mg/100 ml) durante o período de um ciclo em Piracicaba, SP

14 Teores de carboidratos translocáveis (sacarose $-\mathrm{mg} / 100 \mathrm{ml}$ ) em copa de pessegueiro 'Ouromel-2' durante o período de um ciclo em Piracicaba, SP 
15 Comparativo dos teores de carboidratos solúveis $(\mathrm{mg} / 100 \mathrm{ml})$ entre copa e sistema radicular de pessegueiros 'Ouromel 2' durante o período de um ciclo (meses), em Piracicaba, SP ....................................

16 Quantidade de flores, em julho de 1999, de pessegueiros cultivar 'Ouromel-2' submetidos a dois tipos de poda em Piracicaba, SP

17 Quantidade de frutos colhidos em pessegueiros cultivar 'Ouromel-2' submetidos a dois tipos de poda em Piracicaba, SP 


\section{LISTA DE TABELAS}

\section{Página}

1 Teor de carboidratos solúveis totais $(\mathrm{mg} / 100 \mathrm{ml})$ em sistema radicular de pessegueiros 'Ouromel-2' submetidos a dois tipos de poda, em seis épocas do ano, em Piracicaba, SP

2 Teor de carboidratos totais na copa de pessegueiros 'Ouromel-2' $(\mathrm{mg} / 100 \mathrm{ml})$ submetidos a dois tipos de poda, em seis épocas do ano, em Piracicaba, SP

3 Teor de açúcares redutores $(\mathrm{mg} / 100 \mathrm{ml})$ no sistema radicular de pessegueiros 'Ouromel' submetidos a dois tipos de poda, em seis épocas do ano, em Piracicaba, SP

4 Teor de açúcares redutores na $(\mathrm{mg} / 100 \mathrm{ml})$ copa de pessegueiros 'Ouromel-2' submetidos a dois tipos de poda, em seis épocas do ano, em Piracicaba, SP

5 Teor de sacarose $(\mathrm{mg} / 100 \mathrm{ml})$ na raiz de pessegueiros 'Ouromel 2' submetidos a dois tipos de poda, em seis épocas do ano, em Piracicaba, SP 
6 Teor de carboidratos livres (sacarose $-\mathrm{mg} / 100 \mathrm{ml}$ ) na copa de pessegueiros 'Ouromel 2' submetidos a dois tipos de poda, em seis épocas do ano, em Piracicaba, SP

7 Quantidade de frutos colhidos em pêssegos cultivar 'Ouromel-2' submetidos a dois tipos de poda em Piracicaba, SP 


\title{
TEORES DE CARBOIDRATOS EM PESSEGUEIROS (Prunus persica (L.) Batsch.) SUBMETIDOS A DIFERENTES TIPOS DE PODA
}

\author{
Autor: MARCELO REHDER DA CUNHA BORBA \\ Orientador: Prof. JOÃO ALEXIO SCARPARE FILHO
}

\section{RESUMO}

O consumidor exige pêssegos de bom tamanho e boa coloração para consumo "in natura". Estas características de qualidade são resultantes de fatores climáticos, edáficos e das práticas culturais que atuam sobre o produto, além do manejo de pós-colheita. Considerando que a precocidade de maturação vem sendo o principal fator de sucesso econômico ao persicultor paulista, há uma demanda muito grande por novas técnicas de manejo que melhorem a qualidade dos frutos. Várias estratégias visando o aumento de produtividade das plantas e melhoria da qualidade dos frutos são pesquisadas, desde o plantio até a colheita, porém todas elas baseiam-se direta ou indiretamente, do aproveitamento das reservas e das relações entre a demanda de sólidos solúveis e os tecidos de reserva e/ou órgãos produtores de carboidratos. $\mathrm{O}$ trabalho conduzido em um pomar experimental, localizado na Escola Superior de Agricultura "Luiz de Queiroz", em Piracicaba, teve por objetivo estudar os teores de carboidratos solúveis totais, açúcares redutores e carboidratos livres (sacarose) em pessegueiros cultivar 'Ouromel-2', submetidos à dois tipos de poda, poda verde leve e poda verde de renovação. O delineamento experimental utilizado foi o de parcelas subdivididas, com blocos inteiramente casualizados. Cada bloco era constituído de duas parcelas com três 
repetições cada. Por ocasião da instalação do experimento, as plantas encontravam-se com cinco anos de idade, instaladas no espaçamento $6,0 \times 4,0 \mathrm{~m}^{2}(417 \mathrm{plantas} / \mathrm{ha}) \mathrm{e}$ conduzidas no sistema de vaso aberto. As podas foram realizadas logo após a colheita, no final de setembro de 1998, quando da ocasião da instalação do experimento. Foram coletadas amostras de raiz e de ramos, que foram trituradas, secas em estufa, moídas e submetidas à análises de laboratório. Verificou-se os teores de carboidratos solúveis totais, açúcares redutores e carboidratos translocáveis (sacarose) na copa e na raiz das plantas de pessegueiro. Os resultados mostraram que o teor de carboidratos variou de acordo com a época dentro do ciclo da planta. Também mostraram que os tipos de poda interferiram nos teores de carboidratos no sistema radicular, porém não interferiram na copa. Os tipos de poda interferiram na produção do pessegueiro. 


\title{
CARBOHYDRATE CONTENTS IN PEACH TREES (Prunus persica (L.) Batsch.) SUBMITTED TO DIFFERENT PRUNING
}

\author{
Author: MARCELO REHDER DA CUNHA BORBA \\ Adviser: Prof. JOÃO ALEXIO SCARPARE FILHO
}

\section{SUMMARY}

The consumer demands good size and good color of peach for consuming the fruit in natura. These quality characteristics are resulting of climate and edaphic factors, cultural management practices and post-harvest management. Considering that maturing precocity is the principal factor of economic success for of São Paulo state growers, there is a higher demand of new techniques of management that aim the improvement of fruit quality. Several strategies aiming productivity and quality improvement are researched, from planting to harvest, but all of them are based, directly or indirectly, on storage utilization and on relations between the soluble solids demand and storage or carbohydrate production tissues. The experiment, conducted in an experimental orchard, located at Escola Superior de Agricultura "Luiz de Queiroz", in Piracicaba, evaluated total soluble carbohydrates, soluble sugars and sucrose in 'Ouromel-2' peach trees cultivar, submitted to green pruning and renovation green pruning. When the experiment were installed, the peach trees were five years old, planted in $6,0 \times 4,0 \mathrm{~m}^{2}$ distance (417 plants/ha) and conducted in open vase system. The two pruning were done soon after the harvest, in the end of September of 1998. Root and branch patterns were collected, triturated, dried and analyzed. The total soluble 
carbohydrates, soluble sugars and sucrose contents were evaluated on branches and roots of the peach tress. The carbohydrate contents changed during the plant cycle. The kind of pruning interfered in roots carbohydrate contents, but did not interfered in branches contents. The pruning also interfered in the peach production. 


\section{INTRODUÇÃO}

O consumidor exige pêssegos de bom tamanho e boa coloração para consumo "in natura". Estas características de qualidade são resultantes de fatores climáticos, edáficos e das práticas culturais que atuam sobre o produto, além do manejo de pós-colheita (Bender, 1986).

O principal período de safra de pêssegos de mesa no estado de São Paulo, que inicia em final de setembro e prolonga-se até dezembro, é considerado precoce em relação a outras regiões produtores do hemisfério Sul e do próprio Brasil. No restante do país, principalmente em virtude de ocorrência de geadas tardias, são cultivados pessegueiros de maior exigência em frio hibernal, estendendo-se a safra de final de outubro a meados de janeiro, com pico em dezembro-janeiro, quando grande volume do produto é destinado ao mercado da região Sudeste (Nienow, 1997).

Assim, considerando as principais regiões produtores de São Paulo e as diferentes condições climáticas existentes, principalmente temperatura, pode-se considerar a existência de quatro períodos de safra: precoce (Campinas e Itapetininga), medianamente precoce (Atibaia), meia-estação (Mogi das Cruzes e Mairinque) e tardia (Campos do Jordão, Cunha e Guapiara) (Nienow, 1997). Dentro destas regiões, Piracicaba, local deste experimento, encaixa-se em condições semelhantes à região de Campinas, ou seja, com safra precoce.

Considerando que a precocidade de maturação vem sendo o principal fator de sucesso econômico ao persicultor paulista, há uma demanda muito grande por novas técnicas de manejo que melhorem a qualidade dos frutos. Várias estratégias visando o aumento de produtividade das plantas e melhoria da qualidade dos frutos são pesquisadas, desde o plantio até a colheita, porém todas elas baseiam-se direta ou 
indiretamente, do aproveitamento das reservas e das relações entre a demanda de sólidos solúveis, ou seja, o dreno, e os tecidos de reserva e/ou órgãos produtores de carboidratos (fonte).

As relações fonte-dreno e a alocação de carboidratos determinam a produtividade e as características finais do fruto, não só nas culturas comerciais, como em todas as plantas. $O$ crescimento de determinados órgãos das plantas pode ser restrito pela disponibilidade de assimilados (limitação de fonte) ou pela habilidade dos órgãos para utilizar estes assimilados (limitações de dreno). As limitações fonte-dreno podem ser separadas em períodos distintos, ou seja, o crescimento do órgão é principalmente limitado pela fonte em certos períodos durante o desenvolvimento e principalmente limitado por condições de dreno em outros períodos.

O pessegueiro é uma planta caducifólia e que passa por um período de repouso e, portanto, tem em seu ciclo uma fase de acúmulo de carboidratos na forma de reservas, que serão responsáveis pela brotação e desenvolvimento inicial após a quebra da dormência, visto que neste momento a planta encontra-se sem folhas, não tendo condições de produção de carboidratos através da fotossíntese.

\subsection{Ojetivo}

Quantificar as diferenças sazonais de carboidratos presentes em órgãos aéreos e subterrâneos de pessegueiro [Prunus persica (L.) Batsch] cultivar Ouromel-2 submetida a dois tratamentos diferentes de poda verde: poda leve, e poda de renovação, na parte aérea, verificando as variações nos teores de carboidratos solúveis totais, açúcares redutores e carboidratos translocáveis durante todo o ciclo da planta, e sua direta correlação com a produção. 


\section{REVISÃO DE LITERATURA}

\subsection{Origem, Distribuição e Classificação Botânica}

\subsubsection{Origem e distribuição}

O pessegueiro é planta de origem asiática, com centro de origem na China, tendo sido encontradas referências na literatura chinesa de 20 séculos a.C. Também Confúcio em 500 a.C. se referia à sua existência (Simão, 1998). O nome, entretanto, é originário da Pérsia, que foi erroneamente tomada como país de origem, tendo Lineu classificado o pessegueiro como espécie pérsica (Medeiros \& Raseira, 1998). O pessegueiro era também conhecido no mundo greco-romano, no século que antecedeu a Cristo. Provavelmente, teria sido levado da China à Pérsia e daí espalhado pela Europa. Foi introduzido na América do Norte pelos espanhóis, no início do século XVI (Barbosa et al., 1990).

No Brasil, o pessegueiro foi introduzido em 1532 por Martim Afonso de Souza, por meio de mudas trazidas da Ilha da Madeira ou dos Açores e plantadas em São Vicente, São Paulo (Sachs, 1984). Em 1865, segundo o padre Simão de Vasconcelos, constituía cultivo, juntamente com outras espécies, nos campos de Piratininga (Simão, 1998).

\subsubsection{Classificação Botânica}

Os pessegueiros cultivados pertencem à família Rosaceae, à subfamília Prunoideae, ao gênero Prunus, ao subgênero Amygdalus, e à espécie Prunus persica. 
Há referências ainda de outras espécies não cultivadas, a saber: $P$. dadiviana, $P$. mira, P. ferghanensis, e P. kansuensis, originárias da Ásia Ocidental (China), P. andersonii, P. fasciculata, da América do Norte (Barbosa et al., 1990).

À espécie Prunus persica (L.) Batsch são ainda consideradas três variedades botânicas:

a. vulgaris: abrange os pessegueiros cultivados tanto para consumo ao natural como em conserva, derivados de tipos oriundos da Pérsia e do Oeste Europeu (frutos grandes, carnosos e suculentos, com polpa amarela e caroço solto, do Norte da China (fruto carnosos e firmes, com polpa amarela e caroço preso) e do Sul da China (frutos doces, carnosos e suculentos, com polpa branca e baixa exigência em frio hibernal).

b. nucipersica: compreende as nectarinas e os pêssegos sem pelos (fator genético simples e recessivo). Podem apresentar epiderme avermelhada ou creme-esverdeada, polpa amarela ou branca e caroço preso ou solto.

c. platycarpa: abrange as variedades de pessegueiros que produzem frutos achatados no sentido da base para o ápice (fator genético simples e dominante). São do tipo "Peen-to", originários da China, podendo apresentar polpa tanto amarela como branca e epiderme pilosa ou glabra. Adaptam-se ao clima ameno e são cultivados comercialmente em pequena escala (Sachs, 1984).

Essas três variedades botânicas de Prunus persica possuem o mesmo número cromossômico básico, $\mathrm{n}=8$, e somático, $2 \mathrm{n}=16$, e as características comuns de compatibilidade de enxertia e polínica. Genes com dominância simples são responsáveis pelos seguintes fatores: caroço solto, polpa branca, acidez, época de maturação e pubescência dos frutos (Monet, 1983; Ojima et al., 1983).

$\mathrm{O}$ coeficiente de herdabilidade do pessegueiro, ligado aos principais caracteres de interesse técnico ou econômico, são (Hansche, 1986): 0,16 à juvenilidade; 0,39 à data de floração; 0,84 à época de maturação; 0,08 à 
produtividade; 0,31 ao tamanho; 0,13 à firmeza; 0,19 à acidez; 0,01 aos sólidos solúveis do fruto.

A cultivar Ouromel-2, lançada pelo Instituto Agronômico de Campinas em 1983, é considerada uma variedade precoce, com época de maturação em outubro (Barbosa et al., 1990), com ciclo florada à maturação dos frutos de 91 a 120 dias. Dentro do mês de outubro serão avaliados os efeitos dos tratamentos nesta época de maturação.

\subsection{Situação da Persicultura}

O Brasil produz cerca de 140 mil toneladas de pêssegos por ano, sendo o Rio Grande do Sul o estado maior produtor, com média de $80 \mathrm{mil}$ t/ano. O Estado de São Paulo ocupa o segundo lugar, produzindo aproximadamente $28 \mathrm{mil} \mathrm{t} / \mathrm{ano}$. A seguir vem os Estados de Santa Catarina (18 mil t/ano), Paraná (8 mil t/ano) e Minas Gerais (5 mil t/ano) (FNP Consultoria e Comércio, 2001).

O País ainda importa cerca de $3 \mathrm{mil}$ t/ano de frutos frescos, principalmente do Chile (1,3 mil t/ano), Espanha (0,9 mil t/ano) e Argentina (0,5 mil t/ano), e também cerca de 16,8 mil toneladas de pêssego em calda, da Grécia (12,3 mil t/ano) e Argentina (4,3 mil t/ano), comprovando ser a produção brasileira ainda insuficiente para suprir o mercado interno.

O Estado de São Paulo concentra a sua produção em pêssegos de mesa, e tem enfrentado sérios problemas com relação à qualidade dos frutos. A maior parte da área plantada está instalada com cultivares bem precoces e precoces, cuja safra estende-se de final de agosto a novembro. Esta estratégia de produção, adotada pelos persicultores paulistas, visa colocar os frutos no mercado no período da entressafra da produção dos estados sulinos, evitando assim a concorrência com aquela região. 


\subsection{Biologia}

Árvore de crescimento rápido e de pequena longevidade, iniciando a produção a partir do terceiro ano (Simão, 1998).

O pessegueiro, quando deixado a se desenvolver naturalmente, pode atingir mais de $6 \mathrm{~m}$ de altura e sobreviver por 50-60 anos, dependendo do material e das condições edafo-climáticas. Possui, nestas condições, um tronco principal com diâmetro ao redor de $40 \mathrm{~cm}$, de onde se originam as pernadas, ou seja, ramos vigorosos, quatro a cinco, que se afinam à medida que atingem a extremidade da copa.

De acordo com a distribuição das gemas floríferas, os ramos produtivos são classificados em mistos, brindilas dardos e ladrões. Os ramos mistos, mais freqüentes, possuem comprimento variável entre 5 e $100 \mathrm{~cm}$; são portadores de gemas floríferas e vegetativas, terminando geralmente em um do último tipo. Nas brindilas, ramos finos e flexíveis com menos de $30 \mathrm{~cm}$ de comprimento, podem prevalecer as gemas de flor. Seu ápice pode conter tanto uma gema florífera como uma vegetativa. Os dardos, ramos menores, com $5 \mathrm{~cm}$ de comprimento, apresentam gema apical vegetativa e numerosas gemas floríferas. Os ladrões, ramos vigorosos, em geral inúteis para a produção, originam-se da base da planta ou de seu tronco e crescem na posição vertical; podem apresentar ramificação secundária, sempre com gemas vegetativas.

A frutificação ocorre lateralmente sobre ramos longos da estação em crescimento. As gemas frutíferas encontram-se distribuídas em toda a extensão dos ramos mistos, fazendo exceção às vezes o terço inferior e a região apical, que apresentam gemas vegetativas (Simão, 1998). Inicialmente todas as gemas são vegetativas (Brooks, 1970), caracterizadas por uma forma alongada, de cúpia, com os primórdios da folha e estípula circundando o ápice. Quando a iniciação floral começa pode ser observado um alongamento e achatamento do ápice (Bakr et al., 1981). Alguns pesquisadores (Lin et al., 1977) consideram este achatamento como a primeira indicação da iniciação floral. Outros (Barnard \& Read, 1933) consideram a elevação 
do ponto de crescimento, enquanto que Bailey, 1974, considera o inchamento dos tecidos meristemáticos.

As gemas floriferas são simples, mais volumosas e com escamas abertas. As foliares são alongadas, finas e mais ásperas no tato. Quando no ramo isto surgem três gemas num mesmo nó, a central normalmente é vegetativa e as duas externas, floríferas (Simão, 1998).

Barrios \& Guzmán (1985) constataram que a diferenciação floral de pêssego ocorre em um espaço aproximado de 50 a 70 dias. A partir do fim do inverno e começo de primavera predominam as gemas florais.

Seu sistema radicular é, de início, pivotante e, quando adulto, com distribuição lateral de numerosas raízes pouco profundas, explora área aproximada à projeção da copa. Seu ritmo de crescimento acompanha normalmente o da parte aérea, atingindo uma intensidade máxima no início do outono.

Em relação ao sistema radicular do porta-enxerto, Inforzato et al. (1975) observaram que a maior quantidade de raízes (grossas e finas), bem como de raízes finas somente, em peso, foram encontradas até a profundidade de $50 \mathrm{~cm}$ do solo, nas proporções de 96 e $87 \%$ respectivamente. Estes dados permitem a coleta de amostras para análise de carboidratos a uma profundidade muito representativa do total do sistema radicular.

As folhas, duas a quatro por nó ou gema, são do tipo completas, oblongas, lanceoladas ou peninérvias, dotadas de pecíolos curtos. Atingem 4 a $5 \mathrm{~cm}$ de largura por 14 a $18 \mathrm{~cm}$ de comprimento. Apresentam bordas serrilhadas, crenadas ou digitadas e verde escuro durante a fase vegetativa e amarelo esverdeadas no outono. $\mathrm{Na}$ base da lâmina foliar ou em seu pecíolo, uma ou mais glândulas (nectários) estão presentes, podendo ser reniformes ou circulares. A essas glândulas, quando ausentes, correlaciona-se uma suscetibilidade ao oídio. Para proteção dos primórdios foliares, as gemas dispõem, em média, de sete escamas de coloração castanha.

As flores são perfeitas, completas, períginas e normalmente monopistiladas. Diferenciam-se, no início do verão, através de alterações nos 
processos bioquímicos, que condicionam de modo irreversível a morfologia dos meristemas das gemas vegetativas. Podem exibir duas formas: rosácea, de pétalas grandes, bem abertas e róseo claras; e campanulada, de pétalas pequenas, pouco atraentes e róseo escuras. São geralmente autoférteis, à exceção de alguns poucos cultivares. Apresentam cinco sépalas, cinco pétalas e trinta e cinco anteras, dependendo do material; estas podem ser amarelas ou, às vezes, avermelhadas. $\mathrm{O}$ ovário nos pêssegos é pubescente e, nas nectarinas, glabro, com dois óvulos anátropos, sendo um deles abortivo.

O fruto é do tipo drupa, carnoso, com fino pericarpo, mesocarpo carnoso suculento (polpa) e endocarpo lenhoso (caroço). Em geral pode apresentar as seguintes formas: esférico, oblongo, elíptico e ovalado, às vezes com ápice saliente (caso do Ouromel 2). Sua epiderme, quando madura, pode apresentar as seguintes tonalidades: verde, creme ou amarela; de matriz róseo, vermelho ou vinho, variando de 0 até quase $100 \%$ com relação à superficie total do fruto. A polpa pode ser branca, creme, laranja, amarela e até avermelhada. O endocarpo (caroço), comumente ovoidal, pode ser preso, meio preso ou solto e contém, no interior, uma amêndoa dicotiledônea do mesmo formato de seu invólucro. alguns cultivares possuem duas amêndoas em cerca de $20 \%$ dos caroços. O sabor da polpa pode apresentar graduações na faixa de doce acidulado forte ao simplesmente doce, com níveis de $\mathrm{pH}$ e grau Brix, de 3,5 a 5,0 e de 8,0 a 18,0 respectivamente. Quando maduro apresenta em média, para cada $100 \mathrm{~g}$ de polpa, 0,8g de proteínas, 0,2g de gorduras, $13,3 \mathrm{~g}$ de carboidratos, $12 \mathrm{mg}$ de $\mathrm{Ca}$, $26 \mathrm{mg}$ de $\mathrm{P}, 1,10 \mathrm{mg}$ de $\mathrm{Fe}, 5 \mathrm{mg}$ de vitamina $\mathrm{A}, 0,03 \mathrm{mg}$ de vitamina $\mathrm{B}_{1}, 0,06 \mathrm{mg}$ de vitamina $\mathrm{B}_{2}, 28 \mathrm{mg}$ de vitamina $\mathrm{C}$ e 58,20 calorias (Barbosa et al., 1990).

A duração do período de repouso ou a ausência de agentes que conduzam para esse fim determina o limite para esta cultura. Tempo encoberto ou com nevoeiro duplica o efeito das baixas temperaturas, ao passo que a luminosidade e temperatura elevadas, combinada com umidade relativa baixa, aumentam a necessidade de dormência. Em clima tropical, o enfolhamento se torna lento, o florescimento irregular. Esta irregularidade se deve à substância inibidora do 
florescimento, que foi identificada como nerigenin, que decresce no fim do inverno (Simão, 1998).

A frutificação do pessegueiro está baseada na formação anual de ramos mistos, pois os que já floresceram não tornam a fazê-lo. Novos crescimentos terão que ser feitos das partes apicais e basais, ficando dois terços dos ramos sem função, pois são despidos de todo e qualquer órgão. O pessegueiro, quando em formação, emite gemas vegetativas mas, em frutificação, ramos vegetativos exclusivos não são encontrados, a não ser os denominados ladrões, que surgem com freqüência. Os ramos iniciam anualmente suas atividades no início da primavera e paralisam em fins de verão (Simão, 1998).

\subsection{Exigências Climáticas}

O pessegueiro é basicamente uma cultura de clima temperado. Os mais importantes centros de produção comercial situam-se, por essa razão, entra as latitudes de $25^{\circ} \mathrm{N}$ e $45^{\circ} \mathrm{S}$ (Childers, 1976). Em latitudes maiores, a temperatura mínima de inverno e as geadas de primavera são, usualmente, os fatores limitantes. A presença de volumosas massas de água, como grandes lagos e mares internos, pode estender essas zonas de cultivo, agindo como atenuantes do frio (Herter et al., 1998). Áreas continentais, afastadas dos grandes corpos de água, caracterizadas por baixas temperaturas de inverno e por severas geadas primaveris, raramente são centros de produção. Sob condições especiais, em cotas elevadas, o cultivo pode, também, estender-se a regiões tropicais (Diaz et al., 1986).

Apesar de considerado típico de clima temperado, o pessegueiro é hoje cultivado nas mais variadas condições de clima e solo. Encontram-se plantios em regiões com inverno desde bem rigoroso (cerca de 600 a 1200 horas de frio abaixo de $7,2^{\circ} \mathrm{C}$ - parâmetro térmico mundialmente adotado como padrão de exigência climática de frutiferas de clima temperado), até me outras praticamente desprovidas de frio hibernal, perto de 20 horas abaixo de $7,2^{\circ} \mathrm{C}$ (Barbosa et al., 1990). 
Essa adaptabilidade do pessegueiro às diferentes condições climáticas se deve basicamente à seleção genética de cultivares tanto de baixa como de alta exigência de frio. Dessa maneira, o pessegueiro adapta-se a zonas distintas do globo, representadas por clima temperado e mesmo subtropical típicos (Barbosa et al., 1990).

Em decorrência dos trabalhos de melhoramento genético, originaram-se ainda os cultivares com comportamento intermediário marginal, que vegetam $\mathrm{e}$ frutificam satisfatoriamente entre os extremos climáticos (Barbosa et al., 1990).

\subsection{Poda}

O pessegueiro, devido à sua biologia, constitui uma das espécies em que a poda anual de frutificação se impões como obrigatória. A frutificação só ocorre em ramos do ano oriundos de gemas do ano anterior. Depois dela, o ramo perde sua função e, se não for podado, será apenas uma ponte aérea entre a raiz e a parte superior da copa. Essa situação obriga a planta a frutificar cada vez mais distante, opondo, com isso, dificuldades à nutrição. (Simão, 1998). Portanto, é essencial que as árvores sejam forçadas a crescer anualmente.

Raseira et al., (1998), afirmam que não há regra invariável para a poda, sendo necessário, antes de tudo, bom senso e conhecimento dos seus princípios e finalidades e do hábito de frutificação da planta.

A poda é uma operação que reduz o vigor e que pode ser utilizada para manter o tamanho desejado da planta. A poda diminui o tamanho da planta ao mesmo tempo em que proporciona uma nova formação do seu dossel. Deve-se esperar que mexendo-se na copa também se mexa no acúmulo de carboidratos dentro da planta (Faust, 1989). O autor verificou que o metabolismo de carboidratos, especialmente durante o início do crescimento, foi diferente em plantas podadas e não podadas. Além disso, a época em que é realizada a poda interfere de maneira decisiva no crescimento das plantas. Já foi verificado que quando a poda é realizada em plantas dormentes, geralmente fornece maior vigor às plantas, quando comparadas às plantas podadas no verão, que diminui o vigor. 
Diversos tipos de poda de verão podem ser utilizados (Marini, 1985; Barbosa et al., 1999). No estado de São Paulo, tem-se utilizado a poda de renovação, que consiste na poda, após a colheita dos frutos, de todos os ramos da planta, que produziram ou não. Em nossas condições, após a poda, ocorre a brotação, iniciando, assim, o crescimento vegetativo e a diferenciação das gemas para a safra seguinte. Nienow (1997) comparou os dois tipos de poda: a tradicional, realizado no final da dormência e a poda de renovação. Verificou que a poda de renovação realizada no final da primavera, embora tenha retardado o desfolhamento e evitado o florescimento no final do verão, afetou a produtividade do pomar. Porém Marini (1985) estudando podas em plantas dormentes e podas de verão, não constatou nenhuma diferença na produção, tamanho de frutos e época de maturação, nos diferentes tratamentos.

Em relação ao raleio, Pereira et al. (1987) constataram que para espécies tardias, a época de raleio influencia no tamanho final do fruto. Observações poderão ser efetuadas, pois a poda de renovação retardará todo o ciclo da variedade, ficando o raleio mais tardio também, podendo influenciar também na quantidade de frutos por planta.

De qualquer forma, a poda em pessegueiro já está previamente estabelecida e tem como um dos objetivos principais manter o equilíbrio entre o desenvolvimento vegetativo e o reprodutivo, evitando assim a alternância de safras e reduzindo o trabalho de raleio (Callesen \& Wagenmakers, 1989; Olien, 1992; De Jong et al., 1992; Campo Dall'orto et al., 1991).

\subsection{Desenvolvimento do fruto}

O desenvolvimento de frutos de caroço segue uma curva em duplo sigmóide (Conners, 1919; citado por De Jong \& Goudriaan, 1989), com um estádio I, caracterizado pela multiplicação celular, um estádio III, de elongação celular e, entre ambos, um estádio II, onde tem lugar a lignificação do endocarpo e o endurecimento do caroço. O crescimento do fruto é majoritariamente influenciado pelo crescimento do mesocarpo e da sua polpa (Chalmers \& Van Den Ende, 1975). De acordo com a 
precocidade dos cultivares, a duração dos diferentes estádios é variável. O estádio II é, portanto, a passagem de divisão celular ao estádio de crescimento celular. Quando a cultivar tem um desenvolvimento muito rápido, este estádio é apenas perceptível, como ocorre nas variedades precoces. Nestas, o final de divisão celular e o início da diferenciação e crescimento celular são tão rápidas que é dificil detectar o estádio II. Nas cultivares tardias, o desenvolvimento é mais lento e a separação entre os estádios I e II é mais prolongada (Augustí et al., 1997).

Durante as seis a oito semanas seguintes à floração, o crescimento do mesocarpo do fruto tem lugar como conseqüência da divisão celular (Jackson, 1968) e se intensifica com o tempo (Chalmers \& Van Den Ende, 1975), dando lugar a uma curva exponencial. A proliferação celular cessa paulatinamente e depois de um período lento é até nulo, crescimento esse que se reativa de novo como conseqüência do início do alongamento celular. Esse novo período é linear e aumenta até vinte vezes a taxa de crescimento, culminando com o amadurecimento do fruto (Chalmers \& Van Den Ende, 1975).

O desenvolvimento do fruto do pessegueiro depende de sua capacidade para atrair carboidratos produzidos pela fotossíntese (Faust, 1989). As variações no desenvolvimento do fruto estão, entre outros fatores como regulação hormonal (Zucconi, 1986), diretamente relacionadas com a disponibilidade de carboidratos para que possa haver divisão e alongamento celular.

\subsection{Carboidratos}

As substâncias translocadas nas plantas via floema são:

- Água, que é o solvente dos solutos orgânicos, e representa $98 \%$ do total translocado;

- Solutos orgânicos e não orgânicos ( $2 \%$ do total). Destes solutos, $98 \%$ são açúcares e $2 \%$ outras substâncias (compostos nitrogenados, ácidos orgânicos, aminoácidos, ATP, reguladores de crescimento, etc.). 
Os solutos orgânicos são compostos de sacarose (99\%) e verbascose, rafinose, estaquiose, rafinose, etc. (1\%) (Castro, 1985).

A sacarose, translocável via floema, decompõe-se em glucose e frutose, que são os açúcares redutores e não são translocáveis.

Resumidamente, ao incidir a luz nas folhas do pessegueiro, ocorre a fotossíntese, tendo como produto a hexose (podendo ser glucose ou frutose). Em $\mathrm{pH}$ básico ou neutro, com a ação da enzima amilofosforilase, esta hexose acumula-se na forma de amido. Já em pH básico, com a ação da invertase, as hexoses transformamse em sacarose, que são transportadas via floema (Castro, 1985) para as regiões de dreno, podendo ser estas regiões ativas, como desenvolvimento de ramos, flores frutos, etc., ou regiões de armazenamento - tecidos de reserva - nas raízes ou ramos.

De uma forma geral, os açúcares solúveis que proporcionam a energia necessária para o metabolismo da planta são derivados da hidrólise do amido dos tecidos de reserva por ação de enzimas hidrolíticas (Haissig, 1974). Em estudos de variações estacionais com respeito ao efeito de auxinas no enraizamento de estacas e sua relação com a mobilidade de amido de Populos nigra, Nanda \& Anand (1970) consideram que as variações na resposta ao enraizamento são governados por fatores fisilógicos principalmente relacionados com o repouso das gemas, depois do qual se inicia uma fase de crescimento vigoroso, que coincide com a brotação de gemas e renovação da atividade de crescimento. Assim, tanto o baixo rendimento no inverno quando existe alto conteúdo de carboidratos, como durante o crescimento ativo, em que o conteúdo de amido é baixo, demonstra que o amido não se encontra disponível devido a uma inadequada quantidade de auxinas endógenas que coincide com o início do repouso das gemas (Sañudo et al., 1987).

\subsection{Efeito da poda no acúmulo de carboidratos}

O armazenamento de carboidratos é necessário para sustentar o desenvolvimento das plantas em períodos de estresse, durante a dormência, e muito importante durante a iniciação de crescimento e frutificação na primavera (Faust, 
1989). As reservas de carboidratos não estruturados, em frutos de caroço, muda quantitativa e qualitativamente durante os estágios de crescimento dos frutos, e nas plantas durante as estações de crescimento. Augustí et al., (1997) afirmam que a fase III de crescimento de frutos de pêssego se caracteriza por altas necessidades em carboidratos, que se acumulam, ocasionando uma competição entre desenvolvimento vegetativo e reprodutivo durante esta fase. Entretanto, após a colheita, a demanda de carboidrato é reduzida consideravelmente, especialmente se o novo desenvolvimento vegetativo tenha cessado. Logo, o total de carboidratos armazenados necessário para o próximo ciclo de produção dependerá da duração da folhagem no período da colheita, até a caída natural das folhas (Flore, 1994).

Trabalhando com estacas de pêssego, Sañudo et al. (1991) chegaram à conclusão que a concentração de carboidratos totais acumula-se até setembro e começa a diminuir a partir de outubro no hemisfério norte. Transpondo estes dados para nossas condições podemos afirmar que até o fim do verão ocorre acúmulo de carboidratos, começando a diminuir a partir do início do outono, já perto da época de dormência.

Uma planta de pessegueiro em ótimas condições pode desenvolver um grande número de frutos. Tem sido reconhecido que a planta não pode suportar todos estes frutos e produzir frutos de tamanho comercial desejável, produzir suficiente gemas de flores para o ano seguinte, suportar o crescimento de raízes e acumular reservas suficientes para o desenvolvimento no ciclo seguinte (Faust, 1989).

Francisconi et al. (1996) pesquisaram o efeito da intensidade de poda verde em relação à coloração da fruta e constataram que os frutos das plantas podadas com desbaste de $75 \%$ dos ramos do ano foram mais coloridos, seguido pelos das plantas com desbaste de $50 \%$. O desbaste de $25 \%$ dos ramos das plantas não melhorou a coloração dos frutos em comparação com os das plantas testemunhas. 


\section{MATERIAL E MÉTODOS}

\subsection{Local}

O experimento foi conduzido no pomar experimental do Departamento de Produção Vegetal da Escola Superior de Agricultura "Luiz de Queiroz", situado no município de Piracicaba, SP, Brasil, cujas coordenadas geográficas são: latitude $22^{\circ} 42^{\prime} 30^{\prime \prime}$ e longitude $47^{\circ} 38^{\prime} 00^{\prime \prime}$.

\subsection{Clima}

O clima de Piracicaba, conforme a classificação de Köppen, é do tipo Cwa: tropical de altitude, com três meses mais secos (junho, julho e agosto), chuvas de verão e seca no inverno. A temperatura média do mês mais quente é maior do que $22^{\circ} \mathrm{C}$ e do mês mais frio não é inferior a $16^{\circ} \mathrm{C}$, com média de $21,1^{\circ} \mathrm{C}$; precipitação média de $1.253 \mathrm{~mm} /$ ano; ventos predominantes $1^{\mathrm{a}}$ este e $2^{\mathrm{a}}$ sudoeste, com velocidade média de $2,2 \mathrm{~m} / \mathrm{s}$; umidade relativa do ar de $74 \%$ e insolação mensal de 201,5h (2.418 lux/ano). A altitude de Piracicaba é de 546m.

\subsection{Solo}

O solo da área experimental é classificado como Terra Roxa Estruturada, Eutrófica, A moderado, textura argilosa sobre muita argilosa (VidalTorrado \& Sparoveck, s.d.). 


\subsection{A área experimental}

A área do pomar experimental do Departamento de Produção Vegetal utilizada para a condução do experimento é constituída de 40 plantas de pessegueiro cultivar Ouromel-2, enxertadas sobre porta-enxerto cv. Okinawa. Por ocasião do início do experimento (novembro de 1998), as plantas encontravam-se com cinco anos de idade (pós-enxertia), instaladas no espaçamento $6,0 \times 4,0 \mathrm{~m}^{2}$ (417 plantas/ha) e conduzidas no sistema de vaso aberto.

O cultivar Ouromel-2 é de porte médio, com excelente desenvolvimento vegetativo e produtivo. $O$ início da floração e brotação ocorre entre fins de julho e começo de agosto. A maturação dos frutos ocorre de meados de novembro a início de dezembro, porém, particularmente no ciclo estudado, o cultivar apresentou uma maior precocidade, produzindo em fins de setembro. Apresenta frutos de tamanho médio a grande, com peso de $110 \mathrm{~g}$ em média, forma redonda-oblonga e ápice saliente. A película é amarela-esverdeada, com pouca pilosidade. A polpa é de cor amarela, com auréola avermelhada em torno do caroço, que é pequeno e solto, de sabor doce acidulada, bem equilibrado e agradável (Alvarenga \& Souza, 1997).

O cultivar Okinawa, originário do Programa de Melhoramento Genético da Universidade da Flórida, foi obtido de um lote de sementes enviado por Henriz Chikasne, de Okinawa. Trata-se de um porta-enxerto resistente ao nematóidedas-galhas, mas susceptível à raça 3 de Meloidogyne incognita (Raseira \& Nakasu, 1998).

\subsection{Tratamentos}

Poda verde, segundo Fuertes \& Hernandez (1995), é toda a operação de supressão e corte realizada na planta entre o início da vegetação e a caída das folhas, ou seja, durante seu desenvolvimento vegetativo. Este tipo de poda pode debilitar a planta pela supressão das folhas, porém pode ser útil pela supressão de ramos e brotos desnecessários para a produção das plantas. 
Neste experimento, foram utilizados dois tipos de poda verde, que denominamos poda leve e poda de renovação.

Ambas as podas foram executadas em final de setembro de 1998, logo após a colheita dos pessegueiros.

- Poda leve - neste tipo de poda foram suprimidos principalmente os ramos que produziram e brotações em excesso ou mal posicionadas nas plantas (Figuras $1 \mathrm{e}$ 2).

- Poda de renovação: realizada na mesma época que a anterior, porém foram retirado todos os ramos, que produziram ou não, reiniciando o crescimento vegetativo e a diferenciação das gemas para a produção seguinte (figuras 1 e 2).

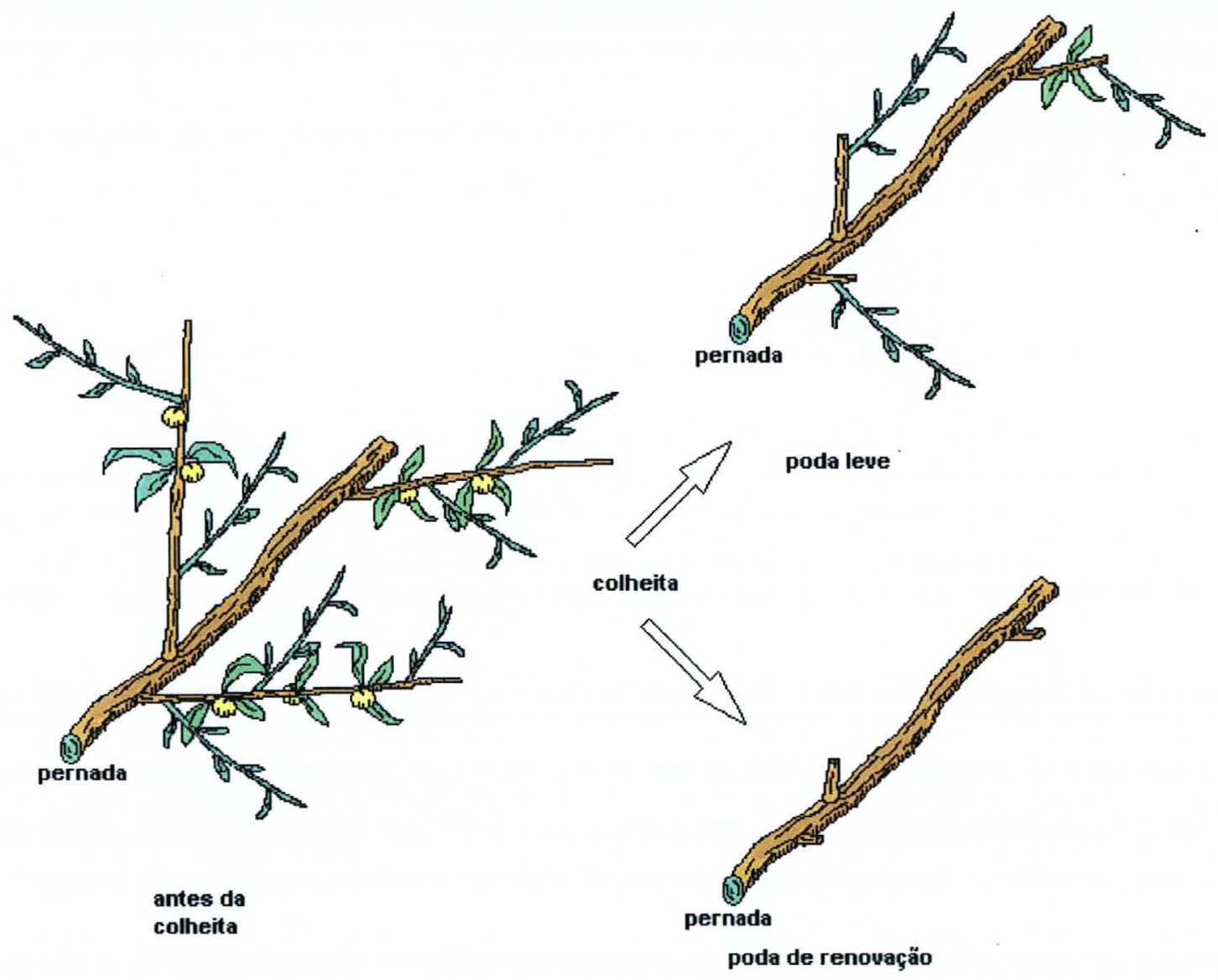

. Figura 1 - Esquema dos tratamentos de podas leve e de renovação realizadas nos pessegueiros, logo após a colheita dos frutos. 


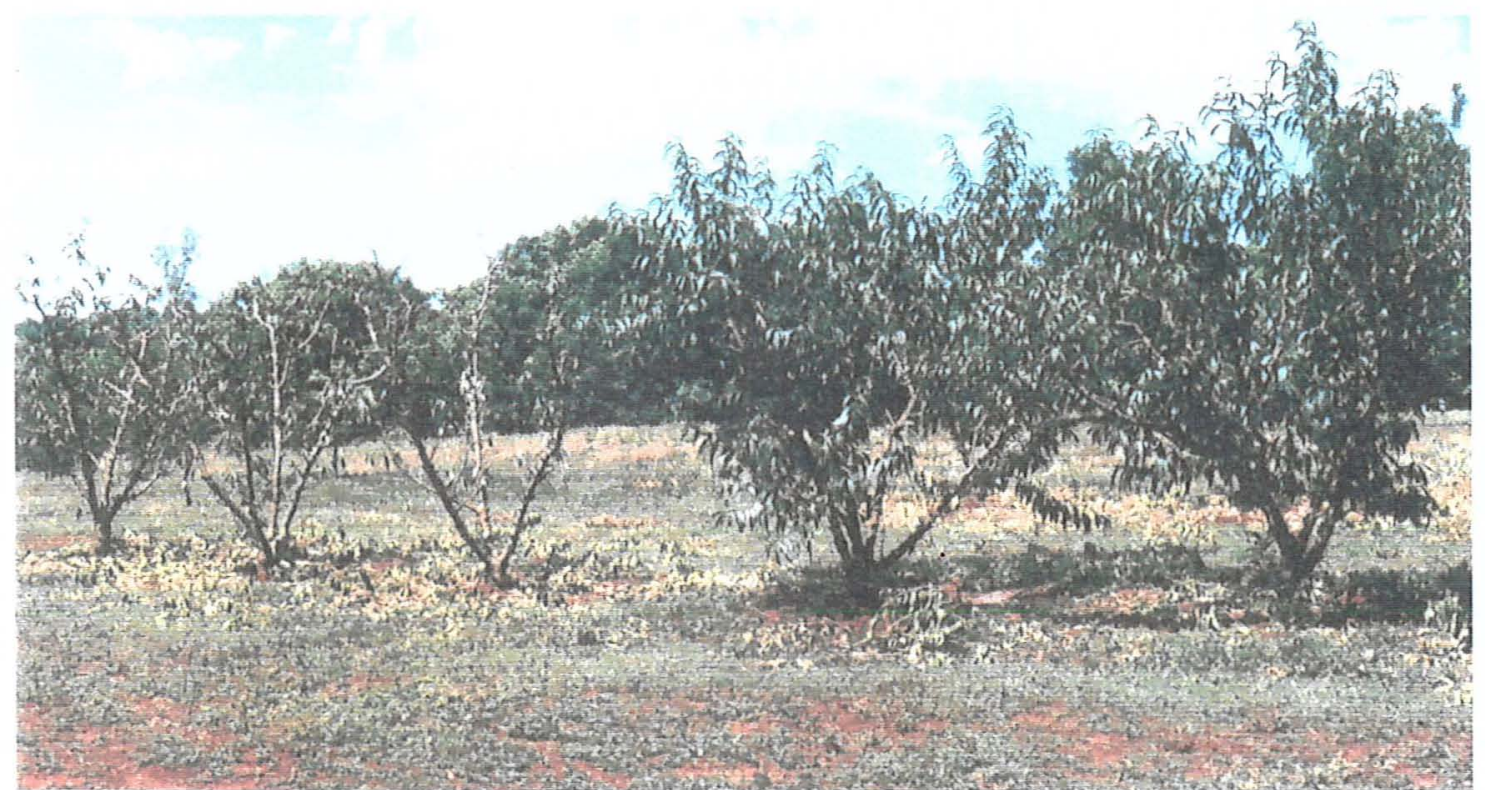

Figura 2 - Diferenças de copas, logo após a poda, entre as plantas submetidas à poda de renovação e com poda leve realizados em pessegueiros Ouromel-2 em Piracicaba, SP.

Foi estudado o efeito destes dois tipos de poda nos teores de carboidratos solúveis totais, açúcares redutores e carboidratos translocáveis nos ramos (parte aérea) e no sistema radicular, durante todo o ciclo do pessegueiro, retirando-se amostras a cada dois meses.

Em novembro de 1998, foram retiradas as primeiras amostras da parte aérea e do sistema radicular das 40 plantas. A seguir retirou-se amostras em janeiro, março, maio, julho e setembro de 1999.

Deste modo tivemos dois tratamentos: fator poda e fator época.

\subsection{Delineamento experimental}

O delineamento experimental utilizado foi o de parcelas subdivididas, com blocos distribuídos inteiramente ao acaso . Cada bloco era constituído de duas parcelas com três repetições cada. O número total de blocos foi de seis (Figura 3). 


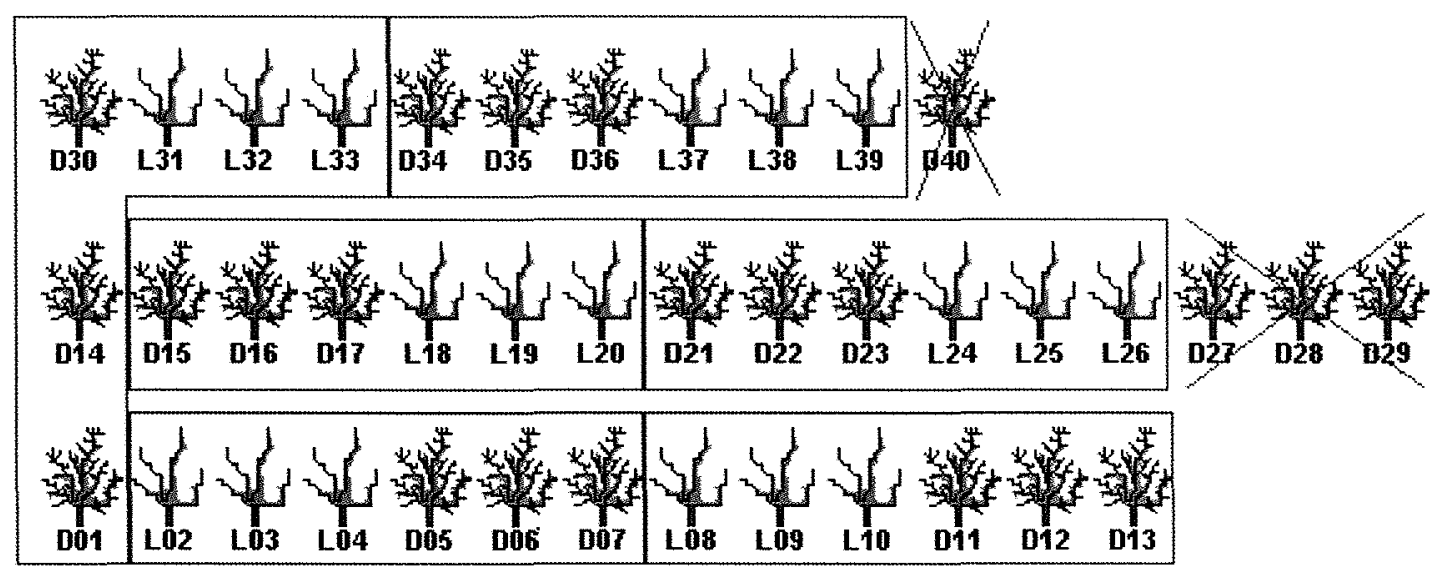

$\mathrm{D}=$ poda drástica

$\mathrm{L}=$ poda leve

Figura 3 - Croqui do delineamento em blocos ao acaso na área experimental da Escola Superior de Agricultura "Luiz de Queiroz", Piracicaba, SP.

\subsection{Retirada e preparo das amostras para análise}

As amostras foram retiradas durante um ciclo da cultura, com intervalo de dois meses entre uma retirada e outra, iniciando-se em novembro de 1998.

As amostras da parte aérea foram coletadas cortando-se segmentos de ramos com mais de 2 anos de idade, a uma distância de $10 \mathrm{~cm}$ da pernada principal. $O$ tamanho das amostras coletadas foi de aproximadamente $10 \mathrm{~cm}$ por ramo, e foram retirados 05 segmentos de ramo por planta. A amostra formada por estes 05 segmentos foi levada à estufa e deixada secar por 96 horas a $65^{\circ} \mathrm{C}$.

As amostras de raiz foram coletadas retirando-se o solo em uma região radial de aproximadamente $40 \mathrm{~cm}$ distante do base do tronco de cada planta. Encontrado o sistema radicular, foram coletados segmentos de ramo de aproximadamente 5 a $10 \mathrm{~cm}$, de raízes sempre com o mesmo diâmetro, de aproximadamente $10 \mathrm{~mm}$. Para estas amostras, devido à maior dificuldade de homogeneização, foram retiradas tantos segmentos quanto possíveis encontrados na região do sistema radicular descrito. Estas amostras também foram secas em estufa, juntamente com as amostras da parte aérea. 
A seguir, as amostras foram trituradas manualmente para poderem ser moídas. Após serem trituradas foram moídas em Moinho de Willie, localizado no Laboratório de Ecologia Aplicada do Departamento de Ciências Florestais da ESALQ. Neste moinho utilizou-se peneira $0,8 \mathrm{~mm}$.

Após esta etapa, as amostras foram encaminhadas para o Laboratório de Nutrição Animal do Centro de Energia Nuclear na Agricultura - CENA para serem efetuadas as análises. Neste local foram analisados os teores de carboidratos solúveis totais e açúcares redutores.

Utilizou-se o método de Somogyi \& Nelson para a determinação de carboidratos totais e de açúcares redutores.

\subsection{Carboidratos analisados}

Foram realizadas determinações dos teores de carboidratos solúveis totais, açúcares redutores e carboidratos translocáveis, que correspondem a:

- Carboidratos solúveis totais: sacarose + hexoses (glucose + frutose);

- Açúcares redutores: hexoses (glucose + frutose);

- Carboidratos translocáveis: sacarose (99\%).

\subsection{Determinação de carboidratos solúveis totais - Método de Somogyi \& Nelson.}

\section{Extração:}

- Pesar, em papel alumínio, $1 \mathrm{~g}$ de material seco e moído

- transferir para erlenmeyer de $250 \mathrm{ml}$

- adicionar $100 \mathrm{ml}$ de água fervente e aquecer em banho-maria $\left(80^{\circ} \mathrm{C}\right)$ por 30 minutos

- filtrar em funil com algodão para balão volumétrico de $500 \mathrm{ml}$

- lavar o erlenmeyer e o algodão com bastante água destilada aquecida 
- completar o volume com água destilada

\section{Preparo dos padrões:}

- solução de glicose $\rightarrow$ dissolver $0,1 \mathrm{~g}$ de glicose em aproximadamente $500 \mathrm{ml}$ de água destilada e transferir para balão volumétrico de $1000 \mathrm{ml}$ completando o volume.

- tomar 4 balões volumétricos de $100 \mathrm{ml}$ e colocar $20 \mathrm{ml}$ da solução de glicose no primeiro, $40 \mathrm{ml}$ no segundo, $60 \mathrm{ml}$ no terceiro e $80 \mathrm{ml}$ no quarto.

- completar o volume de todos os balóes com água destilada

\section{Marcha para determinação:}

\section{Amostras:}

- pipetar, em tubos de ensaio, $2 \mathrm{ml}$ do extrato $\rightarrow$ fazer duas repetições por amostra

- adicionar $1 \mathrm{ml}$ de solução de fenol a 5\%

- adicionar $5 \mathrm{ml}$ de ácido sulfúrico concentrado, em 10 segundos, dirigindo o ácido para o meio da amostra

- deixar em repouso por 10 minutos

- esfriar em água corrente e agitar

- ler em fotocolorímetro, com filtro $510 \mathrm{~nm}$, em absorbância, zerando o aparelho com água destilada

\section{Padrões:}

- repetir o procedimento anterior, lembrando que o padrão 0 (zero) deve ser feito com $2 \mathrm{ml}$ de água destilada.

\section{Preparo da solução de fenol a 5\%:}

Pesar $50 \mathrm{~g}$ de fenol e diluir em becker contendo aproximadamente $50 \mathrm{ml}$ de água destilada. Transferir para balão volumétrico de $100 \mathrm{ml}$ e completar o volume. 


\section{Cálculo:}

Os cálculos são feitos colocando-se os dados em programa existente no computador (Excel $\rightarrow$ cálculos análises $\rightarrow$ carboidratos totais)

\subsection{Determinação dos açúcares redutores:}

\section{Extração:}

- pesar, em papel alumínio, 1 g de material seco e moído

- transferir para erlenmeyer de $250 \mathrm{ml}$

- adicionar $100 \mathrm{ml}$ de água fervente e aquecer em banho-maria $\left(80^{\circ} \mathrm{C}\right)$ por 30 minutos

- filtrar em funil com algodão para balão volumétrico de $500 \mathrm{ml}$

- lavar o erlenmeyer e o algodão com bastante água destilada aquecida

- completar o volume com água destilada

\section{Preparo dos padrões:}

- solução de glicose $\rightarrow$ dissolver $0,1 \mathrm{~g}$ de glicose em aproximadamente $500 \mathrm{ml}$ de água destilada e transferir para balão volumétrico de $1000 \mathrm{ml}$ completando o volume. - tomar 4 balões volumétricos de $100 \mathrm{ml}$ e colocar $20 \mathrm{ml}$ da solução de glicose no primeiro, $40 \mathrm{ml}$ no segundo, $60 \mathrm{ml}$ no terceiro e $80 \mathrm{ml}$ no quarto.

- completar o volume de todos os balões com água destilada

\section{Marcha para determinação:}

\section{Amostras:}

- $\quad$ pipetar, em tubos de ensaio, $2 \mathrm{ml}$ do extrato $\rightarrow$ fazer duas repetições por amostra

- adicionar $1 \mathrm{ml}$ do reativo de Somogyi

- ferver em banho-maria por 15 minutos $\left(80^{\circ} \mathrm{C}\right)$

- esfriar e adicionar $1 \mathrm{ml}$ do reativo de Nelson 
- agitar

- adicionar $6 \mathrm{ml}$ de água destilada

- agitar

- ler em fotocolorímetro, com filtro $540 \mathrm{~nm}$, em absorbância, zerando o aparelho com água destilada

\section{Padrões:}

- repetir o procedimento anterior, lembrando que o padrão 0 (zero) deve ser feito com $2 \mathrm{ml}$ de água destilada.

\section{Preparo dos regentes:}

Reativo de Somogyi $\rightarrow$ Tomar $28 \mathrm{~g}$ de $\mathrm{Na}_{2} \mathrm{HPO}_{4}$ ou $52,9 \mathrm{~g}$ de $\mathrm{Na}_{2} \mathrm{HPO}_{4} .7 \mathrm{H}_{2} \mathrm{O}$ ou $70,6 \mathrm{~g}$ de $\mathrm{Na}_{2} \mathrm{HPO}_{4} \cdot 12 \mathrm{H}_{2} \mathrm{O}$ mais $40 \mathrm{~g}$ de tartarato duplo de sódio e potássio em $700 \mathrm{ml}$ de água destilada.

Adicionar 100ml de $\mathrm{NaOH} 1 \mathrm{~N}$ (4g de $\mathrm{NaOH} / 100 \mathrm{ml}$ solução). Em seguida, gotejar $80 \mathrm{ml}$ de $\mathrm{CuSO}_{4} .5 \mathrm{H}_{2} \mathrm{O}$ a $10 \%\left(10 \mathrm{~g}\right.$ de $\mathrm{CuSO}_{4} .5 \mathrm{H}_{2} \mathrm{O} / 100 \mathrm{ml}$ de solução) sob agitação constante. Juntar $180 \mathrm{~g}$ de $\mathrm{Na}_{2} \mathrm{SO}_{4}$ e completar o volume a $1000 \mathrm{ml}$. Deixar em repouso por 2 dias e filtrar (durante este período as impurezas sedimentam). Guardar o reativo em frasco escuro a mais ou menos $37^{\circ} \mathrm{C}$ para evitar possiveis cristalizações.

Reativo de Nelson $\rightarrow$ Tomar $25 \mathrm{~g}$ de $\left(\mathrm{NH}_{4}\right)_{6} \mathrm{MO}_{7} \mathrm{O}_{24}$ (molibdato de amônio) e dissolver em $450 \mathrm{ml}$ de água destilada. Cuidadosamente, adicionar $3 \mathrm{~g}$ de $\mathrm{Na}_{2} \mathrm{HasO}_{4} .7 \mathrm{H}_{2} \mathrm{O}$ (arseniato de sódio) dissolvidos em $25 \mathrm{ml}$ de água. Manter o reagente em frasco escuro a mais ou menos $37^{\circ} \mathrm{C}$ por $48 \mathrm{~h}$.

Cálculo:Os cálculos são feitos colocando-se os dados em programa existente no computador (Excel $\rightarrow$ cálculos análises $\rightarrow$ açúcares redutores). 


\subsection{Análise estatística}

Os dados coletados foram submetidos à análise de variância (teste F) e, em caso de significância, efetuou-se a comparação múltipla de médias pelo teste de Tuckey ao nível de 5\% de probabilidade. 


\section{RESULTADOS E DISCUSSÃO}

\subsection{Carboidratos solúveis totais nas raízes}

Os tipos de poda estudados interferiram nos teores de carboidratos no sistema radicular, havendo diferença estatística entre os dois tratamentos. A quantidade de carboidratos totais também variou durante o ciclo (Tabela 1, Figura 4).

Tabela 1. Teor de carboidratos solúveis totais $(\mathrm{mg} / 100 \mathrm{ml})$ em sistema radicular de pessegueiros 'Ouromel-2' submetidos a dois tipos de poda, em seis épocas do ano, em Piracicaba, SP.

\begin{tabular}{|c|c|c|c|c|c|c|c|}
\hline \multirow[b]{2}{*}{ Poda } & \multicolumn{6}{|c|}{ Época } & \multirow[b]{2}{*}{ Médias } \\
\hline & Nov 98 & Jan 99 & Mar 99 & Mai 99 & Jul 99 & Set 99 & \\
\hline \multicolumn{8}{|c|}{-...- Teor de carboidratos solúveis totais $(\mathrm{mg} / 100 \mathrm{ml})$} \\
\hline Leve & 234,43 & 243,66 & 253,00 & 262,33 & 223,46 & 202,38 & $236,54 a$ \\
\hline Renovação & 232,51 & 225,53 & 227,83 & 241,31 & 214,87 & 169,28 & $218,55 \mathrm{~b}$ \\
\hline Média & $233,47 \mathrm{a}$ & $234,59 \mathrm{a}$ & $240,41 \mathrm{a}$ & $251,82 \mathrm{a}$ & $219,16 a b$ & $185,83 \mathrm{~b}$ & \\
\hline \multicolumn{8}{|c|}{ C.V. $=13,129 \%$} \\
\hline
\end{tabular}




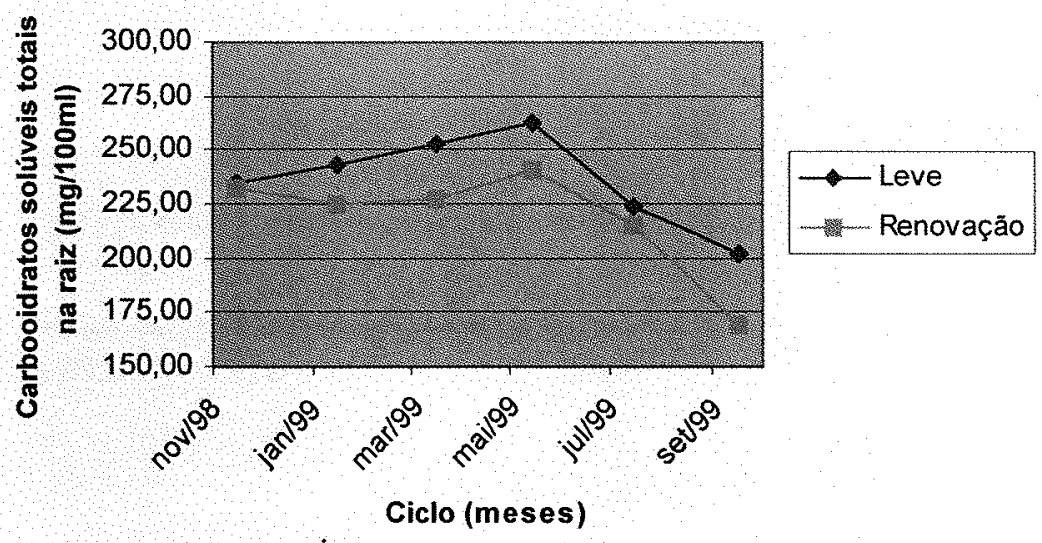

Figura 4 - Efeito de dois tipos de poda no teor de carboidratos solúveis totais $(\mathrm{mg} / 100 \mathrm{ml})$ no sistema radicular de pessegueiros 'Ouromel-2' em diferentes fases de um ciclo, em Piracicaba, SP.

O mês que indicou aos maiores teores de carboidratos, ou seja, o mês de máxima concentração, para os dois tratamentos, foi maio, que corresponde, no ciclo da planta no estado de São Paulo, à época em que a planta está no final do repouso vegetativo.

Os teores de carboidrato vão aumentando a partir de setembro, ou seja, logo após a colheita. No início há um acúmulo maior até novembro e neste período os dados diferem estatisticamente (Tabela 1). A partir de novembro, a planta continua acumulando carboidratos de forma gradual, até maio. Tanto assim que não se observam diferenças estatísticas nos valores de novembro, janeiro e março (Tabela 1). Estes dados nos mostram a importância da manutenção das folhas pelo maior tempo possível após a colheita, ou seja, a importância dos tratamentos fitossanitários para que ocorra esta manutenção e conseqüente acúmulo de carboidratos.

Até novembro de 1998, as plantas vinham sendo conduzidas com o mesmo tipo de poda. Nesta época foram realizados os tratamentos de poda leve e de renovação (Figuras 1 e 2).

Após a poda leve, os teores de carboidrato continuaram aumentando no sistema radicular. Isto era esperado porque neste tipo de poda permanecem folhas nos 
ramos não podados, que transformam fotoassimilados em carboidratos. $O$ tratamento de poda leve foi o que mais acumulou carboidratos (Tabela 1).

Já na poda de renovação, teores de carboidratos totais sofreram ligeiro decréscimo no período de novembro a janeiro. Isto também era esperado pois neste tratamento não foram deixadas folhas (Figuras 1 e 2), e a planta necessitou emitir novos ramos a partir das gemas vegetativas, provavelmente utilizando-se de suas reservas. Neste período observou-se o crescimento dos ramos, conforme Figura 5.

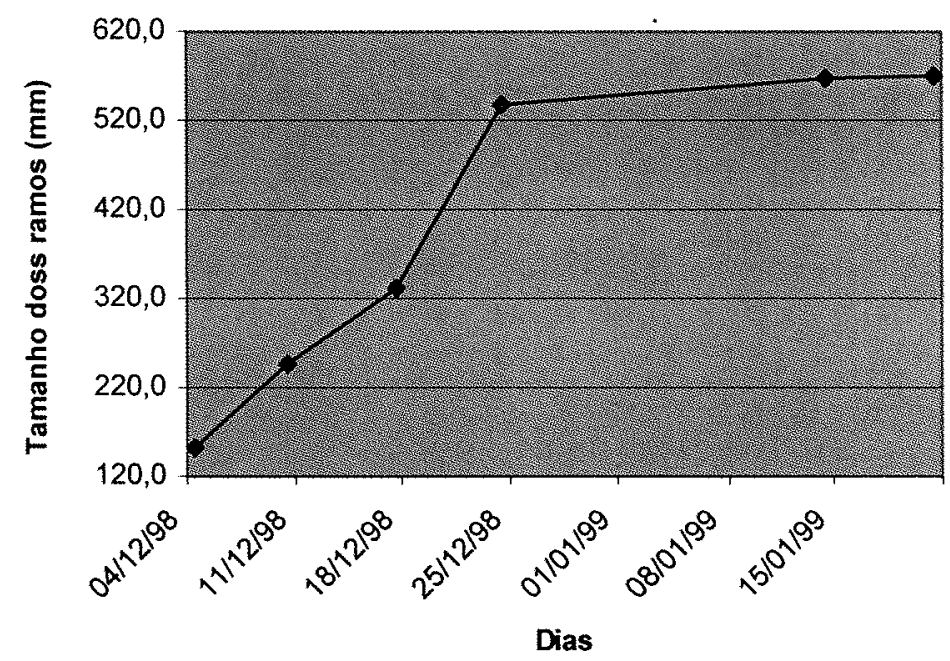

Figura 5 - Crescimento dos ramos novos em pessegueiros 'Ouromel-2' (mm) submetidos ao tratamento de poda de renovação, em Piracicaba, SP.

Os ramos dos pessegueiros atingiram, conforme figuras 5 e 6 , o comprimento médio de $569,80 \mathrm{~mm}$ para as plantas tratadas com poda de renovação. A partir deste ponto cessou o crescimento de ramos.

As plantas com maior desenvolvimento vegetativo (Figura 7) correspondem às tratadas com poda de renovação. Isto se deve à formação de ramos novos, com maior vigor. 


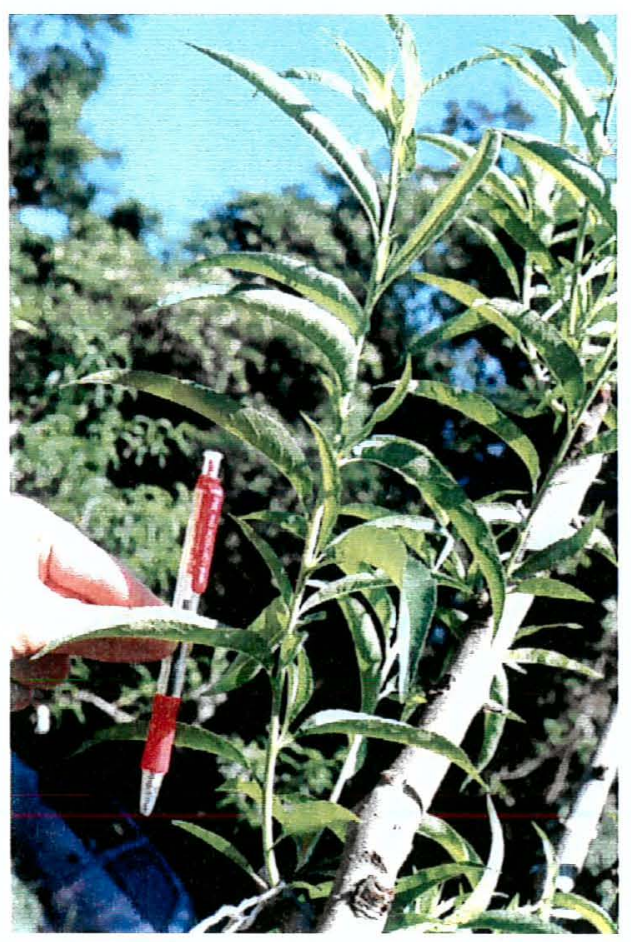

Figura 6 - Ramo em janeiro, no final de crescimento, de pessegueiro cultivar 'Ouromel-2', tratado com poda de renovação, em Piracicaba, SP.

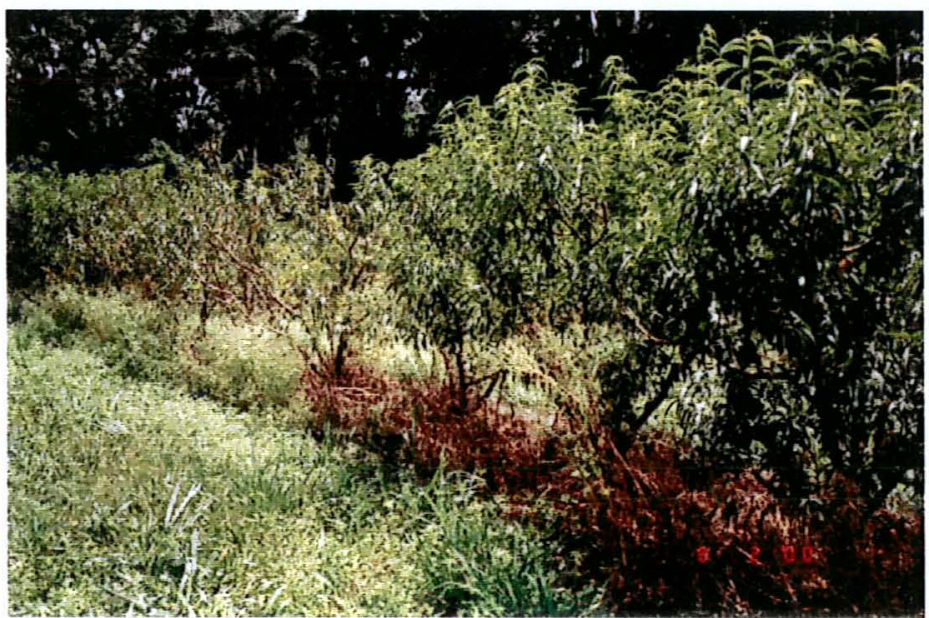

Figura 7 - Diferenças no desenvolvimento de ramos entre pessegueiros cultivar 'Ouromel-2', tratados com dois tipos de poda, em Piracicaba, SP. 
A partir de janeiro, quando os ramos tiveram seu crescimento completado, o acúmulo de reservas nas plantas submetidas à poda de renovação foi semelhante ao acúmulo nas plantas tratadas com poda leve (Figura 4).

Importante observarmos que as plantas tratadas com poda leve não sofreram interrupção no acúmulo de carboidratos, ou seja, este acúmulo foi constante e estatisticamente foi superior ao acúmulo na poda de renovação.

No período compreendido entre maio e setembro, houve queda para os dois tratamentos (Figura 4), pois este período corresponde à brotação, florescimento, pegamento de fruto e o desenvolvimento deste até sua maturação e colheita.

Já no período compreendido entre setembro e novembro, ou seja, o período de pós-colheita, ocorreu armazenamento e os teores de carboidratos solúveis totais aumentaram gradualmente devido à produção de hexoses (frutose ou glucose). Este é o período que antecede ao repouso vegetativo e a planta necessita de suas folhas para acumular reservas, de acordo com Castro, 1985.

\subsection{Carboidratos solúveis totais na copa}

Os teores de carboidratos solúveis totais na copa, tanto para o tratamento de poda leve quanto para a poda de renovação, variaram durante o ciclo. Porém o tratamento poda não interferiu nos teores de carboidratos (Tabela 2). Na copa ocorre dreno constante quando a planta encontra-se fora do período de repouso.

Era esperado um comportamento, ou seja, uma curva semelhante à curva observada para o sistema radicular, porém isto não ocorreu. 
Tabela 2. Teor de carboidratos totais na copa de pessegueiros 'Ouromel-2' (mg/100ml) submetidos a dois tipos de poda, em seis épocas do ano, em Piracicaba, SP.

\begin{tabular}{|c|c|c|c|c|c|c|c|}
\hline \multicolumn{8}{|c|}{ Época } \\
\hline Poda & Nov 98 & Jan 99 & Mar 99 & Mai 99 & Jul 99 & Set 99 & Médias \\
\hline \multicolumn{8}{|c|}{----- Teor de carboidratos solúveis totais $(\mathrm{mg} / 100 \mathrm{ml})$} \\
\hline Leve & 76,80 & 71,93 & 91,34 & 110,74 & 146,98 & 148,48 & $107,71 \mathrm{a}$ \\
\hline Renovação & 80,71 & 77,20 & 89,08 & 104,35 & 140,37 & 140,54 & $105,38 \mathrm{a}$ \\
\hline Média & $78,76 \mathrm{c}$ & $74,57 \mathrm{c}$ & $90,21 \mathrm{c}$ & $107,55 \mathrm{~b}$ & $143,68 \mathrm{a}$ & $144,51 \mathrm{a}$ & \\
\hline C.V. $=13,1$ & $3 \%$ & & & & & & \\
\hline
\end{tabular}

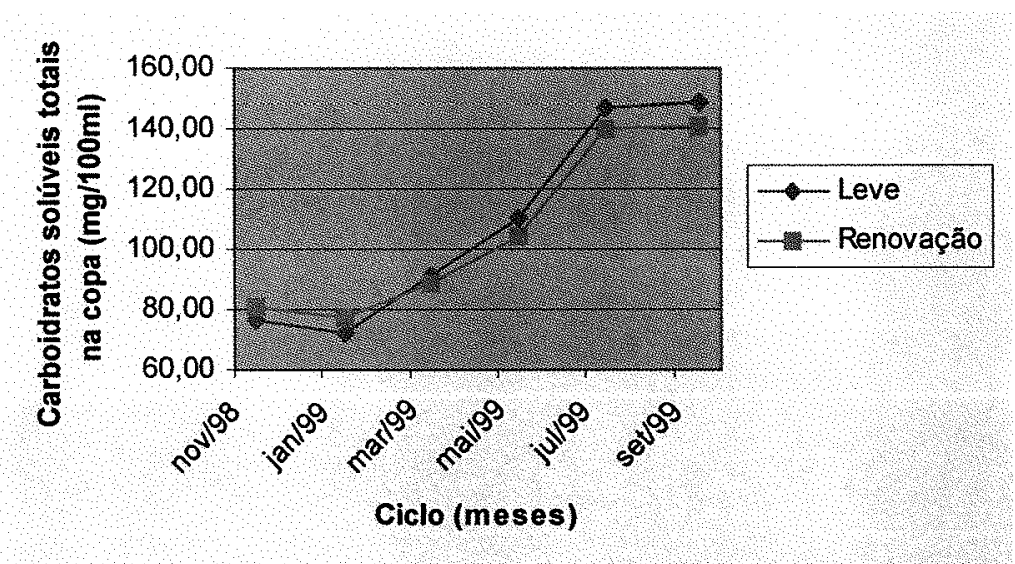

Figura 8 - Efeito de dois tipos de poda no teor de carboidratos solúveis totais (mg/100ml) na copa de pessegueiros 'Ouromel-2' durante o período de um ciclo, em Piracicaba, SP.

O mês de maior teor de carboidratos totais na copa foi setembro, justamente na fase final de frutificação. Isto nos leva a crer que, nesta época, devido ao metabolismo da planta estar em plena atividade, haja um maior teor de carboidratos solúveis, para que se possa atender ao forte dreno originado pelo desenvolvimento dos frutos. De acordo com Augustí et al. (1997), é nesta fase que ocorre o estádio II na 
frutificação e, tanto multiplicação celular quanto elongação celular e lignificação do endocarpo demandam grande quantidade de açúcares, conforme demonstrou Conners (1919), citado por De Jong \& Goudriaan (1989).

Ao contrário do que ocorreu na raiz, após a colheita os teores de carboidratos solúveis totais na copa sofreram uma brusca queda até novembro, permanecendo em níveis baixos até o mês de janeiro (Figura 8).

Nos meses de janeiro a maio pode-se considerar como o período de acúmulo de reservas da planta, correspondente ao final do verão até o início do outono. As folhas estão ativas, atuando como fonte e não ocorre brotação de ramos Neste período os teores de carboidrato na copa permaneceram constantes, sem diferenças estatísticas (tabela 2).

\subsection{Comparação entre carboidratos solúveis totais no sistema radicular e na copa}

Comparando-se os teores de carboidratos solúveis totais na copa e no sistema radicular (Figura 9), pode-se observar que no período em que houve um decréscimo na raiz houve um acréscimo na copa.

De acordo com a Figura 9, ocorrem três períodos distintos no ciclo do pessegueiro, independentemente do tipo de poda ao qual foi submetido: a) acréscimo, tanto no sistema radicular quanto na copa, de carboidratos totais, do mês de novembro (pós-colheita) até maio (final do repouso - desfolha); b) enquanto ocorre decréscimo na raiz, os teores de carboidratos solúveis totais vão aumentando na copa, no período compreendido entre maio e setembro, até ocorrer a maturação plena dos frutos; c) de setembro a novembro, ocorre reposição de carboidratos nas raízes, e decréscimo nos teores da copa, devido à constante translocação para o sistema radicular. 


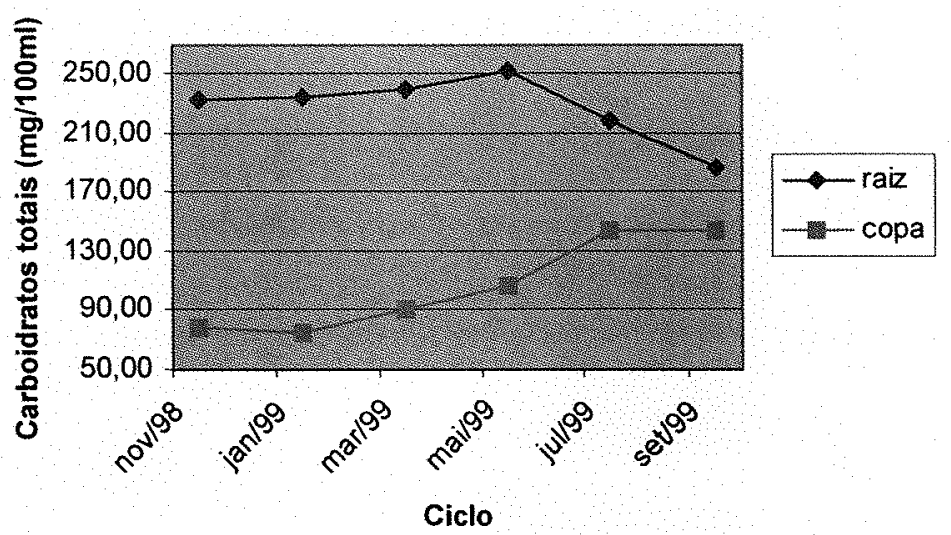

Figura 9 - Comparativo dos teores de carboidratos solúveis totais $(\mathrm{mg} / 100 \mathrm{ml})$ entre copa e sistema radicular de pessegueiros 'Ouromel' durante o período de um ciclo, em Piracicaba, SP.

\subsection{Açúcares redutores no sistema radicular}

De acordo com as Figuras 4 e 10, de novembro a maio ocorre acréscimo tanto nos teores de carboidratos totais quanto de açúcares redutores, no sistema radicular. A partir de maio, quando ocorre o fim do período de repouso vegetativo, ocorre um decréscimo dos teores de carboidratos totais até setembro (colheita), porém neste período os teores de açúcares redutores aumentam em grau absoluto, indicando a maior atividade metabólica na planta, ou seja, o aumento de carboidratos redutores nas raízes indica que estes carboidratos encontram-se em translocação para os drenos originados na copa após o término do período de repouso, ou seja, diferenciação das gemas, desenvolvimento dos ramos e frutos e maturação destes. 
Tabela 3. Teor de açúcares redutores $(\mathrm{mg} / 100 \mathrm{ml})$ no sistema radicular de pessegueiros 'Ouromel' submetidos a dois tipos de poda, em seis épocas do ano, em Piracicaba, SP.

\begin{tabular}{|c|c|c|c|c|c|c|c|}
\hline \multicolumn{8}{|c|}{ Época } \\
\hline Poda & Nov 98 & Jan 99 & Mar 99 & Mai 99 & Jul 99 & Set 99 & Médias \\
\hline \multicolumn{8}{|c|}{ - Teor açúcares redutores $(\mathrm{mg} / 100 \mathrm{ml})$--.-- } \\
\hline Leve & 58,46 & 57,57 & 59,51 & 70,35 & 70,26 & 109,64 & 70,97 a \\
\hline Renovação & 60,61 & 60,66 & 51,06 & 66,22 & 66,27 & 80,82 & $64,27 \mathrm{~b}$ \\
\hline Média & $59,54 \mathrm{c}$ & $59,12 \mathrm{c}$ & $55,29 \mathrm{~d}$ & $68,29 \mathrm{~b}$ & $68,27 b$ & $95,23 \mathrm{a}$ & \\
\hline \multicolumn{8}{|c|}{ C.V. $=12,958 \%$} \\
\hline
\end{tabular}

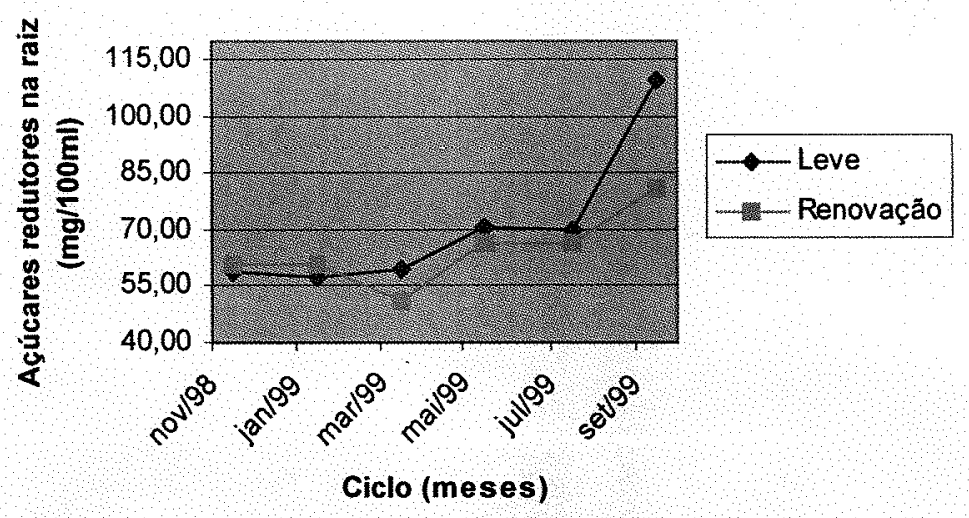

Figura 10 - Efeito de dois tipos de poda no teor de açúcares redutores $(\mathrm{mg} / 100 \mathrm{ml})$ no sistema radicular de pessegueiros 'Ouromel-2' durante o período de um ciclo, em Piracicaba, SP.

\subsection{Teor de açúcares redutores na copa}

A Tabela 4 mostra o comportamento dos teores de açúcares redutores na copa. Semelhante ao comportamento nas raízes, na parte aérea os teores para o tratamento de poda de renovação caem no período entre novembro e março, porém 
começam a aumentar à medida que aproxima-se o fim do repouso até ter sua taxa grandemente aumentada de maio até setembro. Já para a poda leve, estes teores mantém-se estáveis na copa até maio, para depois também terem sua taxa aumentada até setembro (Figura 11).

Este aumento no teor de açúcares redutores, tanto nas plantas tratadas com poda leve quanto com a poda de renovação é resultante, a partir de maio, do término do repouso após a desfolha. A planta passa a ter, até a colheita em fins de setembro, drenos muito fortes na copa, originados pelo desenvolvimento vegetativo e pela frutificação.

Tabela 4. Teor de açúcares redutores na $(\mathrm{mg} / 100 \mathrm{ml})$ copa de pessegueiros 'Ouromel2' submetidos a dois tipos de poda, em seis épocas do ano, em Piracicaba, SP.

\begin{tabular}{llllllll}
\hline \multirow{2}{*}{ Poda } & Nov 98 & Jan 99 & Mar 99 & Mai 99 & Jul 99 & Set 99 & Médias \\
\hline \multirow{2}{*}{ Leve } & 24,01 & 24,94 & 25,87 & 50,96 & 80,40 & 123,2 & $54,90 \mathrm{a}$ \\
Renovação & 35,84 & 35,57 & 29,49 & 39,02 & 60,04 & 110,3 & $51,71 \mathrm{~b}$ \\
Média & $29,93 \mathrm{~d}$ & $30,26 \mathrm{~d}$ & $27,68 \mathrm{~d}$ & $44,99 \mathrm{c}$ & $70,22 \mathrm{~b}$ & $116,75 \mathrm{a}$ & \\
C.V. $=13,009 \%$ & & & & & & \\
\hline
\end{tabular}




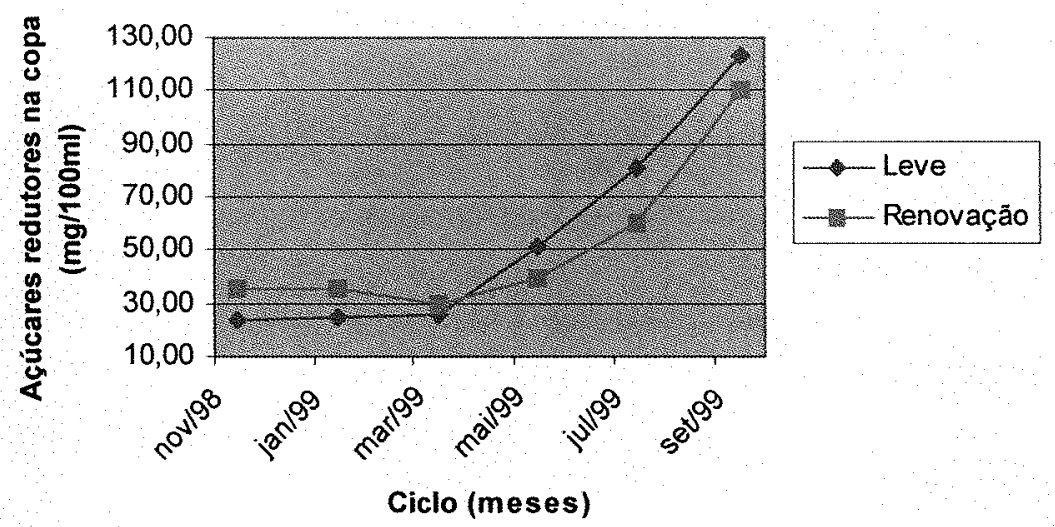

Figura 11 - Efeito de dois tipos de poda no teor de açúcares redutores $(\mathrm{mg} / 100 \mathrm{ml})$ na copa de pessegueiros 'Ouromel-2' durante o período de um ciclo, em Piracicaba, SP.

\subsection{Comparação entre açúcares redutores no sistema radicular e na copa}

Os açúcares redutores, formados por glucose e frutose, não são translocáveis. As baixas concentrações na copa, no período de novembro a maio, são resultantes da baixa atividade proporcionada pelo período de repouso vegetativo. Já na raiz, nota-se que os teores são mais elevados, neste período, do que na copa. Isso se deve à atividade de solubilização das reservas, através da enzima invertase, ou seja, este teor mais elevado é o indicador que estão sendo gastas moléculas de amido dos tecidos de reserva, transformadas em hexoses que formarão a sacarose e será transportada via floema para as regiões de dreno.

A partir de novembro ocorre ligeira queda nos teores de açúcares redutores, porém sem diferença estatística, mantendo-se estes teores em níveis baixos, correspondente ao período de repouso. De março a maio (proximidade do fím do repouso), a planta prepara-se para a diferenciação e brotação, e a quantidade de açúcares aumenta em taxas praticamente iguais tanto para o sistema radicular quanto para a copa. Já a partir de maio, enquanto os teores de açúcares solúveis mantém-se 
estáveis nas raízes, indicando um gasto constante nos tecidos de reserva destes órgãos, a copa tem seus teores aumentados de forma parabólica até o final da maturação dos frutos, indicando a necessidade cada vez maior da planta atender o desenvolvimento de seus órgãos reprodutivos.

Já após a desfolha em maio, com o aumento das atividades na copa, ocorre um grande aumento no dreno originado pela planta do repouso até a colheita, e, à medida que os açúcares redutores aumentam de forma exponencial na copa, nas raízes as quantidades gastas de hexoses aumentam, porém com gradiente mais baixo. Isso se deve ao fornecimento também de hexoses pelas folhas através da fotossíntese.

O ponto culminante, tanto da utilização das reservas da raiz quanto dos novos carboidratos originados pela copa se dá no final da colheita, neste caso em setembro (Figura 12) quando o fruto necessita, além de açúcares para terminar seu desenvolvimento, de reservas para garantir a coloração da epiderme e para aumentar seu grau Brix.

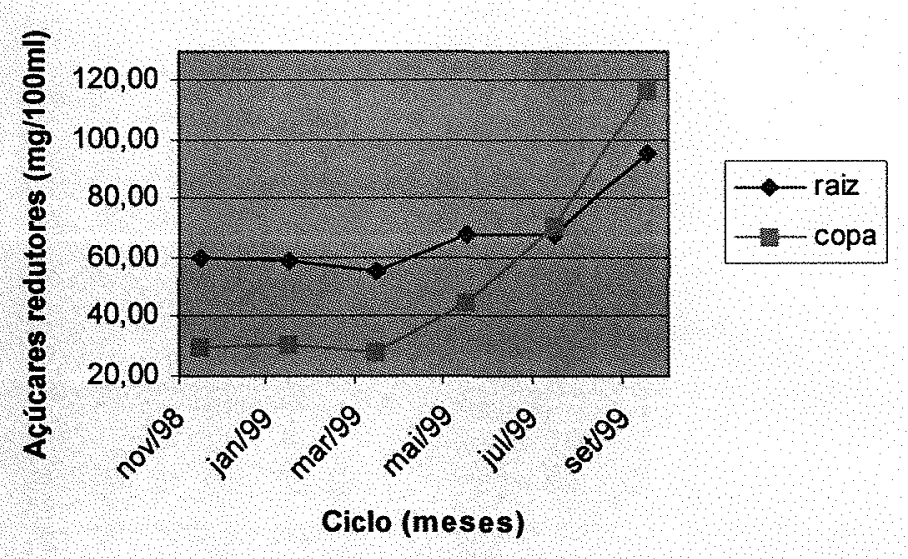

Figura 12 - Comparativo dos teores de açúcares redutores $(\mathrm{mg} / 100 \mathrm{ml})$ entre copa e sistema radicular de pessegueiros 'Ouromel-2' durante o período de um ciclo, em Piracicaba, SP. 


\subsection{Teor de sacarose na raiz}

De maneira inversa ao comportamento dos açúcares redutores, o comportamento da sacarose na raiz inicia em níveis altos em novembro, ou seja, nesta época está correndo a produção de carboidratos nas folhas, que vão sendo translocados para os tecidos de reserva, sempre aumentando seus teores no tratamento de poda leve, até atingir seus maiores níveis no final da dormência (Figura 13). Porém este aumento não tem diferenças estatísticas (Tabela 5).

Para o tratamento de poda de renovação, ocorre um declínio no período de novembro a janeiro, período este utilizado pela planta para desenvolver seus ramos, conforme visto anteriormente.

A partir do término do periodo de repouso (maio, época da desfolha), para os dois tratamentos os teores de açúcares livres vão diminuindo, pois vão sendo utilizados gradativamente pela alta atividade na copa até o fim da colheita (Figura 13).

Os baixos teores de açúcares livres na raiz ao final da colheita confirmam os gastos nos tecidos de reserva que vão disponibilizando cada vez menos carboidratos para a copa. 
Tabela 5. Teor de sacarose $(\mathrm{mg} / 100 \mathrm{ml})$ na raiz de pessegueiros 'Ouromel 2' submetidos a dois tipos de poda, em seis épocas do ano, em Piracicaba, SP.

\begin{tabular}{lccccccc}
\hline \multirow{2}{*}{ Poda } & Nov 98 & Jan 99 & Mar 99 & Mai 99 & Jul 99 & Set 99 & Médias \\
\hline \multirow{2}{*}{ Leve } & 175,97 & 186,09 & 193,49 & 191,98 & 153,20 & 92,74 & 165,58 a \\
Renovação & 171,90 & 164,87 & 176,77 & 175,09 & 148,60 & 88,46 & 154,28 a \\
Média & 173,94 a & 175,56 a & 185,13 a & 183,63 a & 150,90 b & 90,60 c & \\
C.V. = 13,107\% & & & & & & \\
\hline
\end{tabular}

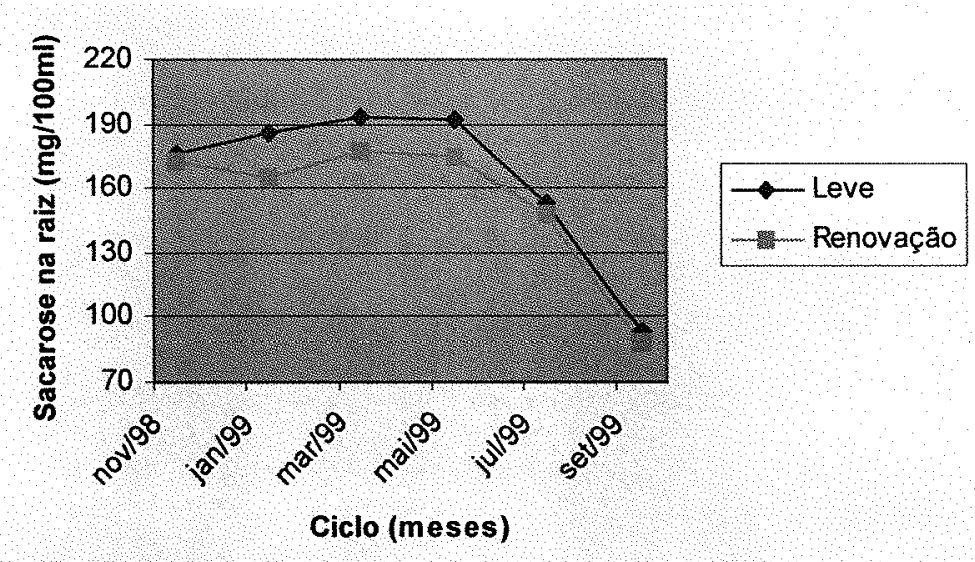

Figura 13 - Teores de sacarose em raízes de pessegueiro 'Ouromel-2' (mg/100 ml) durante o período de um ciclo em Piracicaba, SP.

\subsection{Teor de sacarose na copa}

Não ocorreram diferenças estatísticas para os dois tratamentos durante o ciclo nos teores de sacarose na copa. Deste modo, o comportamento dos açúcares livres foi semelhante para a poda leve e para a poda de renovação (Tabela 6).

De novembro a janeiro houve um decréscimo inicial, porém sem diferenças estatísticas, pois neste período a planta estava acumulando reservas e a 
sacarose estava sendo quebrada em glucose e frutose para acúmulo nos tecidos de reserva sob a forma de amido (tabela 6).

A partir de janeiro cessou o crescimento de ramos e a planta inicia a paralização do crescimento vegetativo. Ocorre uma ligeira queda neste período para o tratamento poda leve, porém sem diferenças estatísticas (tabela 6). Para ambos os tratamentos, os teores de açúcares livres vão aumentando até atingir o pico na colheita. Importante lembrar que a retirada da amostra de setembro foi realizada um logo após a colheita. Isto demonstra a queda brusca nos teores, indicando a diminuição do transporte de açúcares nos vasos quando da parada no forte dreno que é a frutificação (figura 14).

Tabela 6. Teor de carboidratos livres (sacarose $-\mathrm{mg} / 100 \mathrm{ml}$ ) na copa de pessegueiros 'Ouromel-2' submetidos a dois tipos de poda, em seis épocas do ano, em Piracicaba, SP.

\begin{tabular}{lccccccc}
\hline \multirow{2}{*}{ Poda } & Nov 98 & Jan 99 & Mar 99 & Mai 99 & Jul 99 & Set 99 & Médias \\
\hline \multirow{2}{*}{ Leve } & 52,79 & 46,99 & 65,47 & 59,78 & 66,58 & 25,28 & 52,82 a \\
Renovação & 44,87 & 41,63 & 59,59 & 65,33 & 80,33 & 30,24 & 53,67 a \\
Média & 48,83 c & 44,31 c & 62,53 b & 62,56 b & 73,46 a & 27,76 d & \\
C.V. $=13,044 \%$ & & & & & & \\
\hline
\end{tabular}

Maiores teores de carboidratos nos ramos na poda de renovação pode ser explicado pela menor frutificação destas plantas e, conseqüentemente, menor utilização da sacarose pelos frutos. 


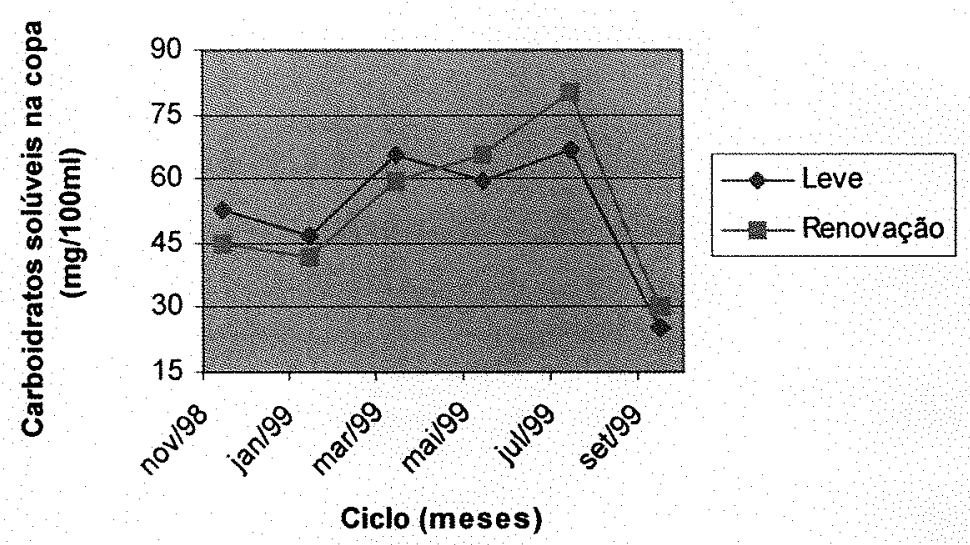

Figura 14 - Teores de carboidratos translocáveis (sacarose - mg/100ml) em copa de pessegueiro 'Ouromel-2' durante o período de um ciclo em Piracicaba, SP.

\subsection{Comparação entre carboidratos translocáveis (sacarose) no sistema radicular e na copa}

Houveram diferenças nos teores de sacarose, tanto na copa quanto no sistema radicular, durante o ciclo. Os teores de açúcares livres e, portanto, disponíveis, foram sempre maiores na copa do que na raiz. Isto ocorre porque durante todo o ciclo o dreno maior ocorre na copa, local de desenvolvimento vegetativo e reprodutivo, enquanto que a demanda por carboidratos na raiz é apenas para atender o crescimento radicular (Figura 15).

A partir de novembro, época em que a planta está em plena atividade fotossintética porém não possui mais o forte consumo de açúcares para a frutificação, ocorre aumento nos teores dos açúcares em movimente, pois a planta está acumulando reservas, e estes açúcares estão sendo transportados para os locais de armazenamento. Isto ocorre até maio, época da desfolha.

Cessada a atividade fotosssintética cessa também aa produção de compostos para reserva, e a taxa de carboidratos disponíveis começa sua queda até o gasto das reservas no final da frutificação em setembro. 
Já para a copa, continuam aumentando os teores de sacarose até o fim da maturação, pois novamente é bom lembrar que a última retirada das amostras foi realizada após a colheita. Portanto, os teores de açúcares disponíveis atingem seu pico na colheita, ou seja, na época que os frutos estão em final de maturação e necessitando de altos teores de açúcar, que em grande parte está sendo translocado dos tecidos de reserva da raiz (figura 15 ).

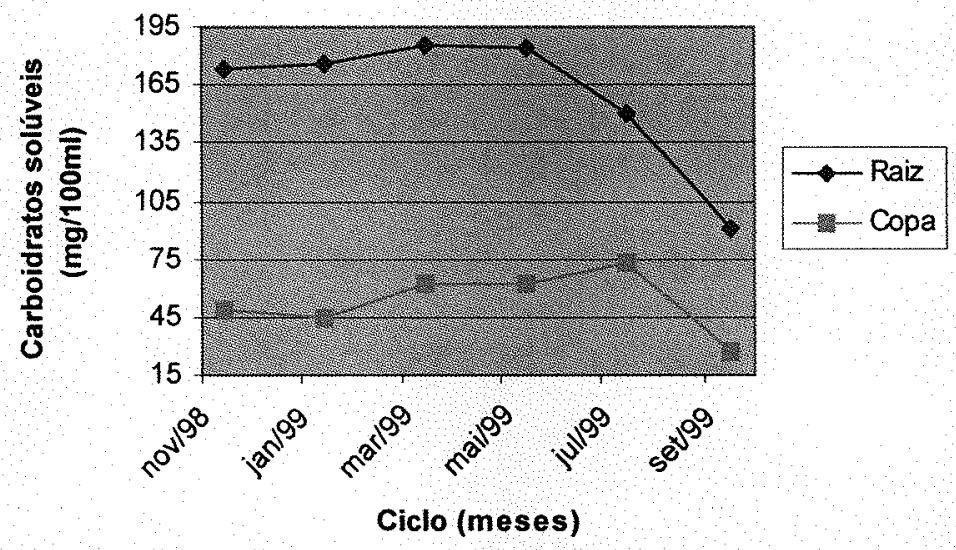

Figura 15 - Comparativo dos teores de carboidratos solúveis $(\mathrm{mg} / 100 \mathrm{ml})$ entre copa e sistema radicular de pessegueiros 'Ouromel 2' durante o período de um ciclo (meses), em Piracicaba, SP.

\subsection{Influência do tipo de poda na produtividade}

As plantas tratadas com poda leve obtiveram um maior número de gemas floriferas e conseqüente maior número de flores (Figura 16). 

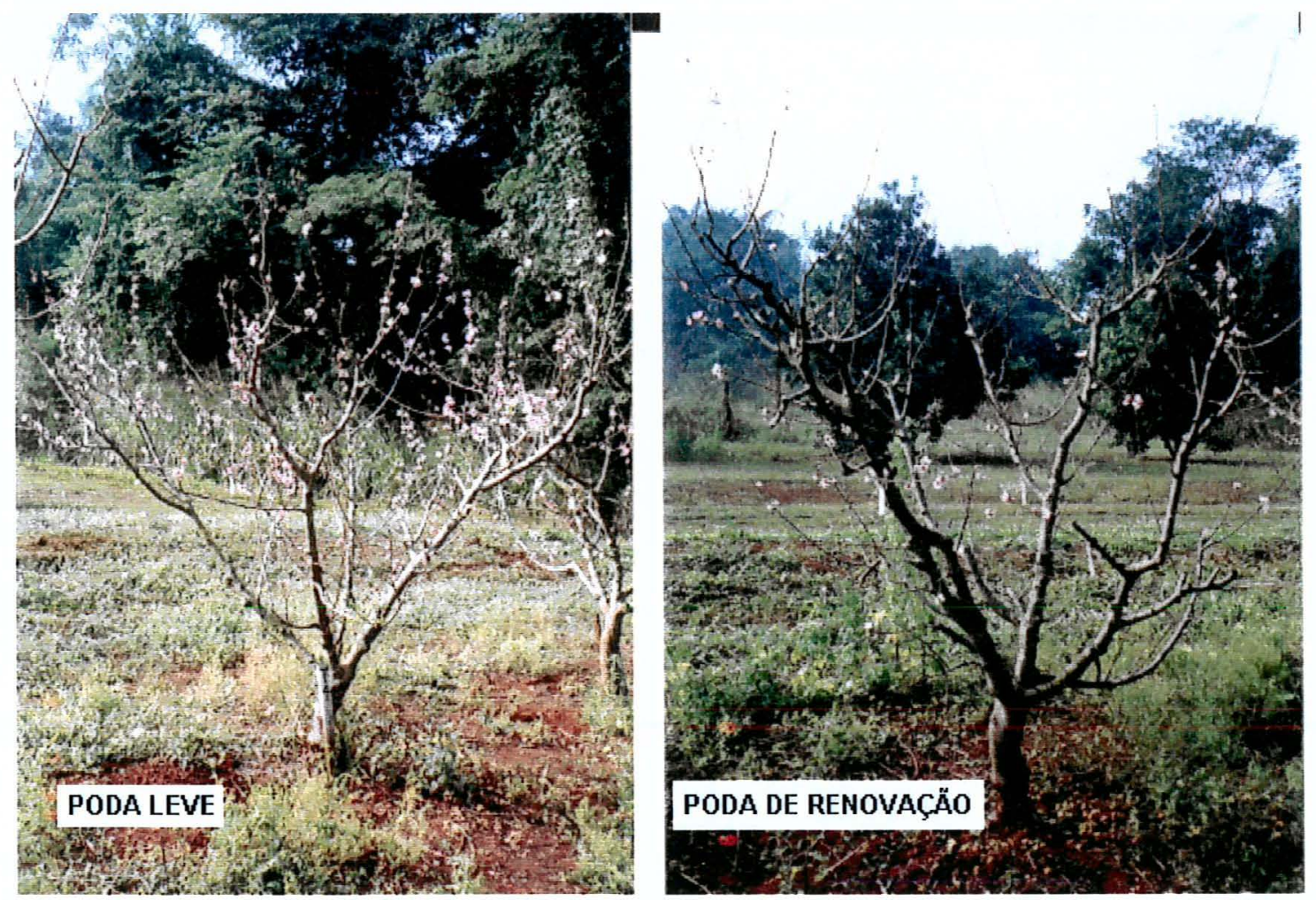

Figura 16 - Quantidade de flores, em julho de 1999, de pessegueiros cultivar

'Ouromel-2' submetidos a dois tipos de poda em Piracicaba, SP.

$\mathrm{O}$ número de frutos colhidos nas plantas submetidas à poda leve foi $102,72 \%$ superior ao número de frutos obtido em plantas submetidas à poda de renovação (Tabela 7 , Figura 17).

Essas quantidades de pêssegos foram obtidas sem realizar-se qualquer tipo de raleio. As quantidades obtidas para o tratamento de poda leve levaram a uma produtividade de $20.509 \mathrm{~kg} / \mathrm{ha}$, estando dentro dos parâmetros fixados por Ojima et al., 1998. Já para as plantas submetidas à poda de renovação, a produtividade foi de $49,33 \%$ da obtida com poda leve, ou seja, $10.117 \mathrm{~kg} / \mathrm{ha}$, estando $49,45 \%$ abaixo do mínimo de produtividade estabelecido por Ojima et al. (1998) para o estado de São Paulo. 
Tabela 7. Quantidade de frutos colhidos em pêssegos cultivar 'Ouromel-2' submetidos a dois tipos de poda em Piracicaba, SP.

\begin{tabular}{lll}
\hline Blocos & Poda leve & Tratamentos \\
\hline 1 & 503 & 279 \\
2 & 318 & 188 \\
3 & 580 & 347 \\
4 & 444 & 225 \\
5 & 531 & 278 \\
6 & 677 & 189 \\
Média & 508,83 & 251,00 \\
\hline
\end{tabular}

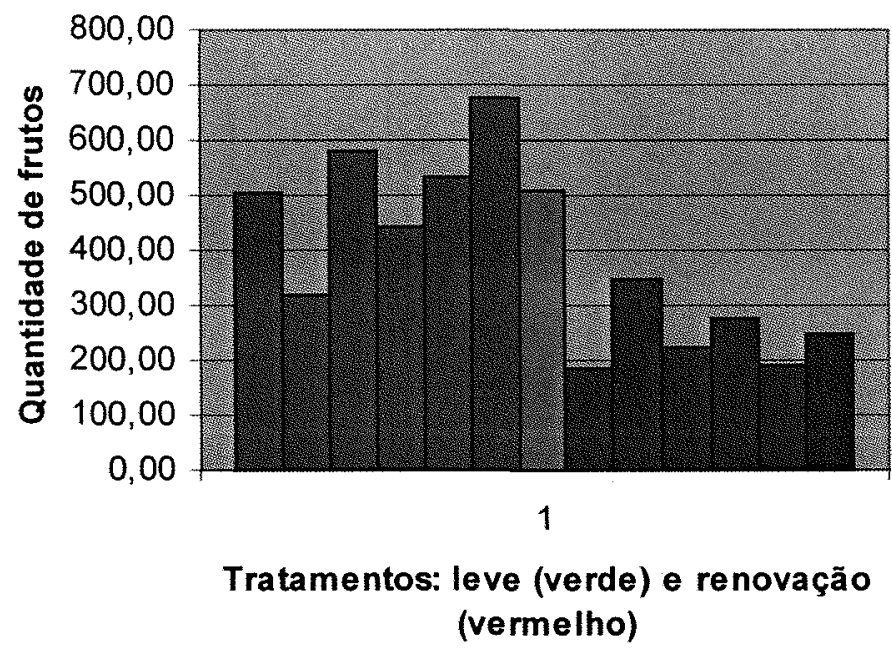

Figura 17 - Quantidade de frutos colhidos em pessegueiros cultivar 'Ouromel-2' submetidos a dois tipos de poda em Piracicaba, SP. 


\section{CONCLUSÕES}

- Os teores de carboidratos variaram de acordo com a época em que foram coletados, dentro do ciclo da planta;

- Os tipos de poda interferiram nos teores de carboidratos no sistema radicular;

- Os tipos de poda não interferiram nos teores de carboidratos na copa;

- Os tipos de poda interferiram na produção do pessegueiro. O tratamento com poda verde leve resultou em produção maior do que as plantas tratadas com poda verde de renovação. 


\section{REFERÊNCIAS BIBLIOGRÁFICAS}

ALVARENGA, A.A.; SOUZA, C.R. Tratos culturais para pessegueiros, ameixeira e nectarinas. Informe Agropecuário, v. 18, n. 189, p.34-43, 1997.

AUGUSTÍ, M.; JUAN, M.; ARMELA, V.; ANDREU, I.; et al. Estimulo del desarollo de los frutos de hueso, Valencia: Generalitat Valenciana, 1997.78 p.

BAILEY, J. S. Autumn development of peach fruit buds. Proceedings of the American Society for Horticultural Science, v.21, p. 30-33, 1974.

BAKR, E. I.; ABDALLA, K. M.; MELIGI, M. A.; et al. Floral differentiation in mango affected by growth regulators, ringing and defoliation. Egyptian Journal of Horticulture., v.8, n.2, p. 161-166, 1981.

BARbosA, W.; CAMPO DALl'ORTO, F.A.; OJIMA, M. Comportamento vegetativo e reprodutivo do pêssego Tropical: cultivar bem precoce no Planalto Paulista. Campinas: IAC, 1990.22 p. (IAC. Boletim Científico, 21).

BARBOSA, W.; CAMPO DALL'ORTO, F.A.; OJIMA, M.; et al. Ecofisiologia do desenvolvimento vegetativo $\mathrm{e}$ reprodutivo do pessegueiro em região subtropical. Campinas: IAC, 1990. 37 p. (IAC. Documentos, 17). 
BARBOSA, W.; CAMPO DALL'ORTO, F.A.;OJIMA, M.; et al. O pessegueiro em pomar compacto: IX. Dez anos de cultivares sob poda drástica bienal. Pesquisa Agropecuária Brasileira, v. 34, n. 1, p. 69-76, 1999.

BARBOSA, W.; OJIMA, M.; CAMPO DALL'ORTO, F.A.; et al. Pêssego; nova classificação dos cultivares do IAC para épocas de maturação dos frutos. O Agronômico, v.42, n.2. p.103-105, 1990.

BARNARD, C.; READ, F. M. A year's observations on growth and fruit bud formation in the apricot and peaches. Journal of Agriculture, v. 31, p. 44-52, 1933.

BENDER, R. J. Colheita e armazenagem. In: EMPRESA CATARINENSE DE PESQUISA AGROPECUÁRIA. Manual da cultura da macieira. Florianópolis, 1986. cap. 12 , p. 521-550.

BROOKS, R. M. Comparative histogenesis of vegetative and floral species in Amygdalus communis, with special reference to the carpel. Hilgardia, v. 13, p. 249-306, 1970.

CALLESSEN, O.; WAGENMAKERS, P.S. Effect of tree density, tree height and rectangulaity on growth, flowering and fruit production. Acta Horticulturae, n. 243, p. 141-148, 1989.

CAMPO DALL'ORTO, F. A.; OJIMA, M.; BARBOSA, W.. Fruticultura: queda de frutos imaturos. O Agronômico, v. 43, p. 2-3, 1991.

CAMPO DALL'ORTO, F. A.; OJIMA, M.; BARBOSA, W.; et al. Januária: nova ameixa de maturação tardia. Bragantia, v.44, n.1. p.505-508, 1985. 
CAMPO DALL'ORTO, F. A.; OJIMA, M; BARBOSA, W.; et al. O nanismo do pessegueiro induzido pela enxertia no damasqueiro japonês. Pesquisa Agropecuária Brasileira, v. 27, n.3. p.517-521, 1992.

CARVAlho, T. C. P.; RASEIRA, M. C. B. Período de floração e percentagem de frutificação efetiva em cultivares de ameixeira japonesa ( $P$. salicina, Lindl), no Rio Grande do Sul. Boletim de Pesquisa Centro Nacional de Pesquisa de Fruteiras de Clima Temperado, n.16. p.5-14, 1989.

CASTRO, P.R.C. Translocação de solutos orgânicos. In: FERRI, M.G. (Coord.) Fisiologia vegetal. São Paulo: EPU, 1985. cap. 5, p. 213-250.

CHALMERS, D. J.; VAN DEN ENDE, B. A reappraisal of the growth and development of peach fruit. Australian Journal of Plant Physiology, v. 2, p. $623-634,1975$.

CHILDERS, N.F. Peach, nectarine, apricot and almond. In: CHILDERS, N.F. (Ed.) Modern fruit science. New Jersey: Rutgers University, 1976. p.328-449.

DE JONG, T. M.; GOUDRIAAN, J. Modeling peach fruit growth and carbohidrate requirements; reevaluation of the double-sigmoid growth pattern. Journal of American Society for Horticultural Science, v. 114, p. 800-804, 1989.

DE JONG, T.M.; DAY, K.R.; DOYLE, J.F.. Evaluation of training/ pruning systems for peach, plum and nectarines trees in California. Acta Horticulturae, n. 322, p. 99-104, 1992.

DIAZ, D.H.; MARTINEZ, J.J.; SHERMAN, W.B. Apple and peach production in warm climates of Northwest Mexico. Fruit Varieties Journal, v.40, n.4, p.121$125,1986$. 
FAUST, M. Physiology of temperate zone fruit trees. New York: John Wiley, 1989. $338 \mathrm{p}$.

FLORE, J. A. Stone fruit. In: SCHAFFER, B; ANDERSEN, P. C.. Handbook of environmental physiology of fruit crops. Boca Raton: CRC Press, 1994. cap. 9, p. 233-270.

FNP CONSULTORIA E COMÉRCIO. Agrianual 2001: anuário da agricultura brasileira. São Paulo, 2001. p. 193-200: Pêssego.

FRANCISCONI, A.H.D.; BARRADAS, C. I. N.; MARODIN, G. A. B. Efeito da poda verde na qualidade do fruto e na produção do pessegueiro cv. Marli. Pesquisa Agropecuária Brasileira, v. 31, n.1. p.51-54, 1996.

FUERTES, M.C; HERNANDÉZ, M.B.D. Poda de frutales y técnicas de propagación y plantación. Madrid: Ministerio de Agricultura, Pesca y Alimentación, 1995. 267p.

HANSCHE, P.E. Heritability of fruit quality traits in peach and nectarine breeding stocks dwarfed by the dw gene. Hortscience, v. 21, n. 5, p.1193-1195, 1986.

HERTER, F.G.; SACHS, S.; FLORES; C.A. Condições edafo-climáticas para instalação do pomar. In: MEDEIROS, C.A.B; RASEIRA, M.C.B. A cultura do pessegueiro. Brasília: Embrapa, SPI, 1998. cap. 2, p.20-28.

INFORZATO, R.; RIGITANO, O.; BARRETO, G. B.; et al. Estudo do sistema radicular do pessegueiro (Prunus persica L. Batsch). Revista de Agricultura, v. 50, n. 1/2. p. 23-28, 1975. 
JACKSON, D. I. Giberellin and the growth of peach and apricot fruits. Australian Journal of Biological Science, v. 21, p. 59-62, 1968.

LIN, G.; SHABANY, B.; RAMOS, D. Pistillate flower development and fruit growth in some English Walnut cultivars. Journal of American Society for Horticultural Science, v. 102, n.6, p. 702-705, 1977.

MARINI, P.M. Vegetative growth, yeld and fruit quality of peach as influenced by dormant prunning, summer prunning and summer topping. Journal of American Society of Horticultural Science, v. 110, n. 2, p. 133-139, 1985.

MEDEIROS, C.A.B.; RASEIRA, M.C.B. A cultura do pessegueiro. Brasília: Embrapa, SPI. 1998. 351p.

MONET, T. Le pêcher: génétique et physiologie. Paris: INRA; Masson, 1983. 133p.

NANDA, K.K.; ANAND, V.K. Seasonal changes in auxin effects on rooting of stem cuttings of Populus nigra and its relationship with mobilization of starch. Plant Physiology, v. 23, p. 99-107, 1970.

NIENOW, A.A. Comportamento morfológico, fenológico e produtivo de cultivares de pessegueiro (Prunus persica (L.) Batsch), submetidos a poda de renovação após a colheita, na região de Jaboticabal/SP. Jaboticabal, 1997. 179 p. Tese (Doutorado), Faculdade de Ciências Agrárias, Universidade Estadual Paulista "Júlio de Mesquita Filho".

OJIMA, M.; CAMPO-DALL'ORTO, F.A; BARBOSA, W. et al. Pêssego. In: FAHL, J.I.; CAMARGO, M.B.P. de; PIZZINATTO, M.A.; et.al. (Ed.) Instruções agrícolas para as principais culturas econômicas do estado de São Paulo. Campinas: IAC, 1998. 396 p. (IAC. Boletim, 200). 
OJIMA, M.; CAMPO-DALL'ORTO, F.A.; RIGITANO, O.; et al. Melhoramento da nectarina em São Paulo. I. Cruzamento de 1970: seleção nas gerações F1 e F2. Bragantia, v. 42, p.1-14, 1983.

OLIEN, W.C. Analysis of orchard training systems for production potencial in a long-term stability. Acta Horticulturae, n. 322, p. 119-123, 1992.

PEREIRA, J. F. M.; FELICIANO, A. J.; RASEIRA, M. C. B.; et al. Curvas de crescimento, época de raleio e previsão do tamanho final do fruto em três cultivares de pessegueiro. Pesquisa Agropecuária Brasileira, v. 22, n.9/10, p.965-974, 1987.

RASEIRA, M.C.B.; NAKASU, B.H. Cultivares: descrição e recomendação. In: MEDEIROS, C.A.B; RASEIRA, M.C.B. A cultura do pessegueiro. Brasília: Embrapa, SPI, 1998. cap.3, p.29-97.

SACHS, S. A cultura do pessegueiro. Pelotas: EMBRAPA, CNPFT, 1984. 156p. (Circular Técnica, 10).

SAÑUDO, R.B.; MONTER, A. V.; DELGADO, M. L. O.; et al. Dinámica y variación estacional de carbohidratos totales durante la iniciación y diferenciación de raíces en estacas de durazno (Prunus persica L. Batsch) seleccion F8215. Agrociencia, n.68. p. $155-162,1987$.

SIMÃO, S. Tratado de fruticultura. Piracicaba: FEALQ, 1998. 760 p.

VIDAL-TORRADO, P; SPAROVECK, G. Mapa pedológico detalhado do campus “Luiz de Queiroz", Universidade de São Paulo. Piracicaba, s.d. (Escala 1:10.000). 
ZAR, J. H. Bioestatistical analisys. 2.ed. Englewood Cliffs: Prentice Hall, 1984. $718 \mathrm{p}$.

ZUCCONI, F.. Peach. In: MONSELISE, S.P. (Ed.) Handbook of fruit set and development. Boca Raton: CRC Press, 1986. cap. 4, p. 58-96. 